\title{
Osmanlı İlerleyişi Esnasında Trakya Şehirlerinin Durumu Hakkında Bir Değerlendirme
}

\section{An Evaluation of the State of Thracian Cities During the Ottoman Conquest}

\author{
Hacer Ateş' ${ }^{1}$
}

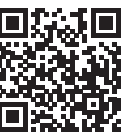

'Sorumlu yazar/Corresponding author: Hacer Ateş (Dr. Öğr. Üyesi), Trakya Üniversitesi, Edebiyat Fakültesi, Tarih Bölümü, Edirne, Türkiye.

E-posta: hacerates@trakya.edu.tr ORCID: 0000-0002-0708-0213

Başvuru/Submitted: 01.02.2021 Revizyon Talebi/Revision Requested: 10.02.2021

Son Revizyon/Last Revision Received: 27.03.2021

Kabul/Accepted: 27.03 .2021

Atıf/Citation: Ateş, Hacer, “Osmanlı Ilerleyiş̧i Esnasında Trakya Şehirlerinin Durumu Hakkında Bir Değerlendirme”, Güneydoğu Avrupa Araştırmaları Dergisi, 37 (2021), s. 125-156

https://doi.org/10.26650/gaad.8720368

öz

Osmanlı Beyliği'nin teşekkülünün ilk yıllarında Bizans'ın Bithynia bölgesi beyliğin kuruluş coğrafyasını oluştururken, Trakhia bölgesi ise Balkanların fethini hazırlayan ana yerleşim sahasını teşkil etmiştir. Trakya bölgesi, imparatorluğun başkenti Konstantinopolis'e batıdan gelebilecek muhtemel saldırıların bertaraf edildiği savunma hattını oluşturmaktadır. Gelibolu, Dimetoka ve Edirne gibi şehirler bu hattın en önemli noktalarını teşkil etmektedir. XIV. yüzyılda Trakya'da cereyan eden hadiseler mezkûr kentlerin güçlerini kaybetmesine sebep olurken, bölgede Bizans hâkimiyetini de zayiflatmıştır. Yaşanan bu gelişmeler Osmanlıların Trakya'ya geçmesine vesile olmuştur. Orhan Bey zamanında VI. loannes Kantakuzenos'la kurulan ittifak neticesinde Trakya'ya ayak basan Osmanlı kuvvetleri çok geçmeden burada kalııı olmayı başarmışlardır. Bu çalışmada Trakya'da yaşanan hadiselerin bölge şehirleri üzerindeki etkileri ve bu sürecin Osmanlıların ilerleyişine katkısı ele alınmıştır.

Anahtar Kelimeler: Bizans, Trakya, Rumeli, Osmanl, Dimetoka, Edirne

\section{ABSTRACT}

The Byzantine province of Bithynia served as the core area for the newly emerging Ottoman Principality in Asia Minor, whereas the Trakhia served as the main settlement zone in the Balkans. The latter also became the main defensive line to protect Constantinopolis - the capital of the Empire - from any external threats from the west. The cities of Gelibolu (Gallipoli), Dimetoka (Demotica) and Edirne (Adrianople) were the most important urban centers located in this Balkan frontier zone. While the developments of the 14th century weakened the Byzantine power and caused an urban decline, it contributed to the Ottoman penetration into the region. The Ottoman forces first crossed into Thrace following Orhan Bey's alliance with loannes Kantakuzenos VI, which turned into a permanent settlement zone within a short period of time. The present paper deals with the impacts of the 
historical events in Thrace on the history of the afore-mentioned urban centers as well as on the process of Ottoman penetration into the region.

Keywords: Byzantine, Thrace, Rumelia, Ottoman, Demotica, Adrianople

\section{EXTENDED ABSTRACT}

Ottoman Turks named Thrace as Rumelia. This name was also used in the Balkans. Thrace region was the intersection of the roads connecting Asia, Europe and Anatolia. It is a very strategic region for this. For this reason, it was frequently invaded by those who wanted to take it over. XIII. At the beginning of the century, the crusaders invaded the region and captured Constantinople, the capital of the Byzantine Empire. The emperor, who was expelled from the capital, re-established a state in Nikaia. However, years later, he saved Konstantinolios and settled in the capital again. Byzantine Empire IV. It lost its former power after the crusade. XIV. Since the beginning of the century, it has been attacked from all sides. Turks captured in Anatolia. Serbs and Bulgarians continued to threaten the Byzantines on European soil. Emerging as a small state in the territory of Byzantium, the Ottomans captured the Bithynia region in a short time. After that, they wanted to cross to the European side and capture other Byzantine lands. The bad conditions of the Byzantine Empire made it easier for the Ottomans. XIV. The isyna and civil wars that started towards the second half of the century put the country even more difficult. Thrace region was affected the most in this process. The safety of Konstantinolopis was endangered. The search for allies in the struggle between the rival powers against each other has led to events that will cause Thrace to be lost. Ottomans with Thrace XIV. met in the middle of the century. The Thrace region is very important for the security of Constantinople, the capital of the empire. There were cities with strong walls such as Gallipoli, Dimetoka and Edirne. Most of the Byzantine cities were characteristic Medieval cities that stood out with their military features, known as the castrum surrounded by walls. They had strong ramparts protecting these cities. For this reason, it was difficult to get them. The Ottomans applied the classical policy of siege to get them. They began to suppress the mighty walls. The Ottomans passed to Thrace for the first time as an ally of the joint Emperor Kontakouzenous. Relations started during the time of Ottoman Sultan Orhan. Ottoman soldiers went to Thrace shortly after. This situation gave them the opportunity to get to know the region. Later they started to act independently. The weak Byzantine administration was not in a position to resist this. The situation of the Byzantine people worsened day by day. The people of the cities could not get out of the castles out of fear. The farms of the peasants were plundered. Farmland was damaged in wars. The Beret Thracian lands are now barren like a desert. The peasants left their places. they settled in safer cities. Farms thus remained empty. Sending wheat to Constantinople ended. Food prices increased in the capital. Byzantine administration tried to overcome this crisis with foodstuffs brought by Genoese sailors. However, this was a very 
expensive solution. Byzantium could not cope with these difficulties very much. The people in Thrace waiting for help from the emperor were disappointed. These bad conditions they had created an opportunity for the Ottomans. This situation enabled them to progress in a short time. Ottoman conquests accelerated. Thracian cities surrendered to the Ottomans one by one. In a period of ten years, the Thracian lands were now under the control of the Ottomans. This situation caused a crisis in the Byzantine rule. The co-emperor abdicated. Constantinople was threatened enough. This place became the new target of the Ottomans. The Ottomans settled the Turks they brought from Anatolia to the Thrace region they conquered. Thus, new Turkish villages, cities and neighborhoods were established. They created new residential areas. Most of the Byzantine farmers had abandoned their lands. Turks started farming in places left empty of them. When Thrace came under Ottoman rule, the chaos in the region ended. Wars ended, the region became safe. This atmosphere of trust has relaxed the public and their fears have ended. Some of the farmers who left their places returned to their villages and started farming. With the new farms established by the Turks, agricultural lands became fertile again. The Ottomans made arrangements not only in villages but also in cities. In some cities, they repaired the destroyed castle walls. They built new ports. Cities that were destroyed during the Byzantine period were revived. Cities have started to get crowded now that they are safe. Many immigrants continued to come from Anatolia. Thracian cities have become safe, rich and crowded cities. It moved from its Ottoman capital Bursa to Edirne. Edirne also became a military base. The Ottomans, who settled in Tarkya, started to organize their expeditions first to the Balkans and then to the interior of Europe. 


\section{Giriş}

Batılı seyyahlar, XIII. yüzyılda Türklerin idâresindeki Anadolu'yu Turquemenie (Turquie) ve Bizans İmparatorluğu'na tâbi yerleri Romanie (Romania) ismiyle zikretmekteydiler. Nihayet bu tâbir, daha ziyade Ortodoks Yunan mezhebinin hâkim bulunduğu Balkan Yarımadası'nı ifade etmeye başladı. Osmanlı Türkleri, Balkanlar için Rum-ili adını Romania'dan aldılar ve Anadolu'ya karşı denizin ötesinde Bizanslılardan fethettikleri bölgeler için kullandılar. ${ }^{1}$ Modern kaynaklarda, Trakya bölgesinin Rumeli olarak adlandırılması ise bazı yazarlar tarafından eleştirilmiştir. Türklerin Rumeli ismini, imparatorluğun Avrupa yakasında bulunan bütün topraklarına verdikleri veya çok özel olarak da Arnavutluk ve Makedonya'nın bir parçasını içine alan idârî kesimlerden birine bu adı verdiklerinden bahsedilmektedir. ${ }^{2}$ Ancak bu toprakların bazı Bizans kroniklerinde Trakya olarak zikredildiği, hatta yer yer Makedonya olarak adlandırıldığı dikkat çekmektedir. Kronik yazarları Trakya ve Makedonya coğrafî sınırları mefhumunu farklı ifade ettiklerinden bilhassa Trakya'nın Makedonya olarak kaydedildiği daha sık görülmektedir. ${ }^{3}$ Imparator I. Iustinianos (527-565) zamanında Trakya bölgesinin biraz daha geniş bir alanı târif etmek için kullanılması yanında Trakya, Mora ve Gelibolu (Khersonesos) Yarımadası'nı da içine alarak İyonya Körfezi boyunca Bizans'ın sahillerini kapsadığı görülmektedir. ${ }^{4}$ Fakat Bizans idârî teşkilât şeması incelendiğinde Trakya ve Makedonya bölgelerinin ayrı ayrı coğrafyalar olduğu görülecektir. ${ }^{5}$

Bölgenin coğrafî sınırları dönemlere göre değişiklik arz etse de Asya ile Avrupa'nın kesişerek boğazlar vasıtasıyla Anadolu'ya uzandığı bir güzergâh üzerinde yer alması burayı bir çekim alanı hâline getirmiştir. Bu sebeple stratejik önemi hâiz bölge sık sık farklı milletlerin istilâsına mâruz kalmıştır. Bahsedeceğimiz dönemle bağlantılı olarak ele alacak olursak mezkûr coğrafya bilhassa XIII. yüzyılın başında Lâtin istilâsıyla birlikte neredeyse Bizans İmparatorluğu'nun sonunu getirecek olaylara sahne olmuştur. 1204 yılındaki IV. Haçlı Seferi neticesinde Avrupa'daki topraklarının büyük bir kısmını Lâtinlere bırakmak zorunda kalan Bizans idâresi, başkent Konstantinopolis'i dahi kaybederek Anadolu'daki mevcut topraklarında yeniden hayat bulmaya çalışmıştır. ${ }^{6}$ Konstantinopolis'in elden çıkması Bizans idâresinde

1 Halil İnalcık, "Rumeli”, DIA, C. XXXV, İstanbul 2008, s. 232.

2 Tuncer Baykara, Türkiye üzerine çalışan bazı araştırmacıların yer isimlerini hatalı kullandıklarından bahsederek Rumeli isminin de yanlış bir kullanıma mâruz kaldığına değinmiştir. “... Türkiyénin Avrupa'da bulunan kısmını dört yönetim bölgesine ayırmadan edemez ve bu arada Trakya bölgesine Rumeli adını verir; halbuki Türkler Rumeli diye, imparatorluğun Avrupa yakasında bulunan bütün topraklarına derler veya çok özel olarak da Arnavutluk ve Makedonya'nın bir parçasııı içine alan idârî kesimlerden birine bu adı verirler...", Tuncer Baykara, Anadolu'nun Tarihi Coğrafyasına Giriş I-Anadolu'nun Idari Taksimatı, Ankara 1988, s. 154.

3 Şahin Kılıç, Bizans Kısa Kronikleri, İstanbul 2013, s. 74.

4 Procopius, Bizans'in Gizli Tarihi, çev. Orhan Duru, İstanbul 2001, s. 115.

5 Tuncer Baykara, a.g.e., s. 15-17.

61204 Nisan'ında Lâtinler tarafından zapt edilen Konstantinopolis'ten ayrılmak zorunda kalan Thedoros Laskaris 1208'de Nikaia'da (İznik) tacını giyerek imparatorluğunu ilân etti. Bizans kilisesi ve devleti İznik'te yeniden doğdu. Bkz. Georg Ostrogosky, Bizans Devleti Tarihi, çev. Fikret Işıltan, Ankara 2011, s. 388; Donald M. Nicol, Bizans'in Son Yüzyılları 1261-145, çev. Bilge Umar, İstanbul 2016, s. 14; İsmail Koçuk, İznik Bizans Devleti Tarihi Kuruluş Devri (1204-1214), İstanbul Üniversitesi Sosyal Bilimler Enstitüsü Basıımamış Yüksek Lisans Tezi, İstanbul 2017. 
büyük bir travmaya sebebiyet vermiştir. Zîra yüzyılın ikinci yarısında başkent geri alınsa bile bundan sonra batıdan gelebilecek her türlü tehdit başkentin elden çıkma korkusuyla birleşmiştir. Bu nedenle ülkenin genel güvenlik politikasının âdeta Konstantinoplis'in korunması esasına bağlı olarak geliştiği ve alınan tüm tedbirlerin bu yönde olduğu anlaşılmaktadır. Doğu tarafında başkentin güvenliğini Sakarya savunma hattı boyunca sıralanmış bölgenin önemli kale-şehirleri sağlamaktaydı. Güneyde ise Hellespont (Çanakkale) Boğazı'nın Anadolu'dan gelebilecek saldırılara karşı doğal bir savunma hattı oluşturacağı düşünülmekteydi. En çok endişe duyulan ve en büyük tehlikenin gelebileceği yer olarak tasavvur edilen batı yönünde ise Meriç Nehri boyunca bir hat oluşturulup Konstantinopolis'in güvenliğinin sağlanabilmesi tasarlanmaktaydı. Ancak yaşanan gelişmeler karşısında Bizans'ın savunma projeleri bu beklentileri karşılamak şöyle dursun alınan tedbirler, başkentin korunmasını sağlayamadığı gibi XIV. yüzyılın sonlarında büyük toprak kayıpları ile neticelenmiştir.

Bizans idârecileri XIV. yüzyılın başlarından itibâren imparatorluğun doğu sınııındaki Türkmen akınlarının kendileri için pek yakında büyük bir tehlike olabileceğini düşünmüyorlardı. Ancak Selçuklu-Bizans sınıında uzun yıllardır etkin bir görevi üstlenen müstahkem sınır şehirleri şiddetini daha da arttıran bu akınlar karşııında birer birer Türklere teslim oluyorlardı. Bizans İmparatorluğu bu bölgede Bursa, İznik, İzmit gibi önemli kentlerini çok geçemeden yanı başında günden güne güçlenen Osmanlılara bırakmak zorunda kalmıştı. ${ }^{8}$ Nihayetinde Osmanlılar boğazın Anadolu yakasına kadar ilerlemişler ve artık Bizans'ın başkenti Konstantinopolis'i doğudan tehdit eder hâle gelmişlerdi.

Büyük endişe yaratan bu hareketlilik Marmara'nın güney-batı sahillerinde de belirmeye başlamıştı. Başkentin savunmasında diğer doğal bir koruma hattı olan Çanakkale Boğazı da tehlike altında idi. ${ }^{9}$ Nitekim gerek askerî gerekse iktisâdî noktadan ehemmiyeti sebebiyle Şark İmparatorluğu'nun müdâfaası hususunda Çanakkale Boğazı'ndan daha mühim bir nokta bulunmamaktaydı. ${ }^{10}$ Ancak Çanakkale bölgesi Türkmen Beyliklerinin tehdidi altında idi. Osmanlıların Bitinya taraflarında ilerlediği sıralarda Batı Anadolu'da kurulan beylikler de arazilerini Bizans aleyhine genişleterek üzerlerine sevk edilen Bizans ordularını yenmekteydiler. XIV. yüzyılın başında Anadolu'daki Türk beylikleri Bizans'ın sahil kentleri Manisa, Alaşehir, Sard gibi hâlâ

7 Batı'ya ve içte yaşanan meselelere odaklanan Bizans idârecileri ilk başlarda Türkmenlerin, bulunduğu bölge ile yetinebileceklerini düşünmekteydiler. Bkz. Ali Sevim-Yaşar Yücel, Türkiye Tarihi - Fetih, Selçuklu ve Beylikler Dönemi, Ankara 1989, s. 238.

8 Yaklaşık 10 yıldan fazla bir süre herhangi bir yardım alamayan Bursa halkını perişanlığa ve açlığa mahkûm eden abluka yüzünden şehir Osmanlılara teslim edilmiştir, Halil İnalcık, “Bursa”, DiA, C. VI, İstanbul 1998, s. 446-449. Bursa'nın fethi hususunda ayrıca bkz. Âşıkpaşazâde, Tevârih-i Âl-i Osman, haz. N. Atsız, Osmanlı Tarihleri-l, İstanbul 1949, s. 110-111. Daha önce ablukaya alınmış olan İznik ise 1331'de Orhan Bey zamanında ele geçirilmiştir (h. 731), bkz. Âşıkpaşazâde, s. 118-119. Ayrıca bkz. Mehmed Neşrî, Kıtâb-ı Cıhan-Nümâ (Neşrî Tarıhı), yay. haz. Faik Reşit Unat-Dr. Mehmed A. Köymen, I. Cilt, Ankara 1949, s. 157-159. İzmit ise 1333 yılında kuşatma altına alınmış, 1337'de Osmanlılara teslim olmuştur. Halil İnalcık, "Osmanlı Sultanı Orhan (1324-1362) Avrupa'da Yerleşme", Belleten, LXXIII, sayı: 266, s. 81. Bu hususta ayrıca bkz. Âşıkpaşazâde, s. 116-117.

9 Nicol, a.g.e., s. 270.

10 Fevzi Kurtoğlu, Gelibolu ve Yöresi Tarihi, İstanbul 1938, s. 27. 
Bizans nüfuzu altında bulunan yerleri şiddetle muhasara ediyorlardı. Türk korsanlar da Marmara Denizi'ne girmiş ve başkentin önündeki adaları ele geçirmişlerdi. ${ }^{11}$ Bizans yönetimi bu durumun üstesinden gelebilmek için Alanlar ve Katalanlarla ittifak kurma yoluna gitmişti. ${ }^{12}$ Katalan lideri Roger de Flor'un gönderdiği elçilerle görüşmeler devam ederken bir yandan da Alanlar Batı Anadolu'ya geçirilmişti. ${ }^{13}$ Katalan birlikleri Batı Anadolu'da Türkler tarafından kuşatılan bazı şehirleri kurtarmayı başardılarsa da kontrolden çıkarak kentleri yağma ve tahribe başlayınca Bizans idâresi gelişmeleri kontrol edebilmek üzere bahsi geçen birlikleri Trakya'ya geçirmek gibi bir çözüme başvurmuştur. Nitekim bu süreç Katalanlar tarafından Trakya'nın yağmalanması ile neticelenecektir. Katalanların Batı Anadolu'da beklentileri karşılayamaması neticesinde Bizans idâresinin en çok güvendiği ikinci savunma hattı da çatırdamaya başlamıştır.

XIII. yüzyılın sonlarından itibâren Avrupa topraklarındaki durum ise Anadolu'dan farksız değildir. Sırp Krallığı, Stefan Milutin devrinden itibâren Makedonya toprakları için imparatorluğun batı sınırlarını sürekli baskı altında tutmakta ve 1282'den itibâren Üsküp'ü ele geçirdikten sonra Kuzey Makedonya'ya sızmaya devam etmekteydiler. ${ }^{14}$ Kuzey sınırını ise Bulgar Krallığı tehdit etmekteydi ve hududu geçip Hadrianopolis (Edirne) kentine saldırmışlard.. ${ }^{15}$ Kuzey yönünde Bulgarların saldırıları, batıdan Sırpların istilâları, Arnavutluk bölgesinde ise devam eden isyanlar, iktidar mücadeleleri ve iç savaşlar imparatorluğa oldukça güç kaybettirmişti. II. Andronikos (1282-1328) ve halefleri devrinde ülkede iç karışıklıklar ve isyanlar âdeta birbirini kovalamıştır. Venedik ve Cenevizliler ise Ege adalarından birçoğunun denetimini ele geçirmişlerdir. ${ }^{16}$ Nikeforos Gregoras, XIV. yüzyılda genel durumu değerlendirirken "Lâtinler ve Frenkler Bizans'ın bütün gelirlerine el koydular, limanlarında vergileri topladılar ve aynı zamanda hazineyi talan ettiler!"17 sözleriyle Bizans'ın iktisâdî vaziyetinin ne derece kötü durumda olduğunu ifade etmektedir.

11 Şerif Baştav, Bizans Imparatorluğu Tarihi Son Devir (1261-1461) Osmanlı Türk-Bizans Münasebetleri, Ankara 1989 , s. 21.

12 Bizans'ın bu doğrultuda politikaları için bkz. Zerrin Günal Öden, “Bizans İmparatorluğu'nun Türkler'e Karşı Alan ve Katalanlar ile İttifakı", İstanbul Üniversitesi Edebiyat Fakültesi Tarih Dergisi, S. 35, İstanbul 1994, s. 125-129.

13 II. Andronikos'un girişimleri sonucu imparatorluğun Batı Anadolu'daki topraklarını Türklere karşı korumak üzere Bizans hizmetine giren Alanlar daha ilk çatışmada Türkler karşısında hezimete uğrayınca bölgeden ayrılmak zorunda kalmışlardır. Bunun üzerine imparatorluk için diğer bir alternatif olan Katalanlarla ittifak zorunlu hâle gelmiştir. Katalanlarla uzlaşma yolları aranırken nihayet Katalanların yüksek ücretle Bizans'ın hizmetine girmesi teklifi kabul edildi. Katalanların yardım karşılığında talep ettikleri ücretler her ne kadar Bizans'ın bütçesini zorlasa da imparatorluğun kabul etmekten başka çaresi kalmamıştır. Roger de Flor'un emrindeki soylular ve pek çok şövalyenin de aralarında bulunduğu 1.500 süvari, 4.000 hafif silâhlı piyade (Almugaver) ve ayrıca 1.000 piyade ile birlikte aileleri de Bizans'ın hizmetine girmişlerdir. Bkz. Yusuf Ayönü, Katalanların Anadolu ve Trakya'daki Faaliyetleri (1302-1311), Ege Üniversitesi Yayınları No:158, İzmir 2009, s. 29-32.

14 Nicol, a.g.e., s. 150. 1282'den sonra Üsküp devletin merkezi olmuştur. Böylece Üsküp'te 110 yıl devam edecek Sırp hâkimiyeti başlamıştır. Sırp Çarı Stefan Duşan 16 Nisan 1346'da imparator unvanını alarak Üsküp'te taç giydiği bilinmektedir. Bkz. Mehmet İnbaşı, “Üsküp”, DiA, C. XLII, İstanbul 2012, s. 377.

15 Nicol, a.g.e., s.164.

16 Nicol, a.g.e., s. 229.

17 Yannis Kordatos, Bizans'in Son Günleri, çev. Muzaffer Baca, İstanbul 2006, s. 15. 
İktisâdî, askerî ve siyasî anlamda büyük bir girdabın içinde olan Bizans İmparatorluğu genel olarak bakıldığında XIV. yüzyılın ortalarında Anadolu'da topraklarını Türklere terk etmiş, Tesalya ile Epeiros'u Sırplar işgal etmiş, günden güne küçülen ülkenin çekirdek bölgesini ise Konstantinopolis ile Trakya teşkîl eder hâle gelmiştir. İşte bu bölgede ise hayatî öneme sahip Dimetoka (Didymoteikhon) ile Edirne kentleri bulunmaktadır. ${ }^{18}$ Bizans idâresi bundan sonra daralmış sınırlarını ve Avrupa'daki topraklarını muhafaza etmek için tüm dikkatini Trakya bölgesine vermiştir. Bu çalışmada Trakya bölgesinde ehemmiyet kesbeden şehirlerin nitelikleri, askerî ve siyasî misyonları ele alınarak XIV. yüzyılda yaşanan hadiselerin kentler üzerinde yarattığı etkiler ve bu gelişmelerin Osmanılıarın bölgede ilerleyişine katkıları ele alınacaktır. Osmanlıların Trakya bölgesine geçişleri birçok çalışmada ele alınmakla birlikte ekseriyetle Gelibolu'dan geçiş ve akabinde devam eden hadiselere yer verilmiştir. Ancak bölgenin genel vaziyetine, Osmanlı fütuhatını kolaylaştıran ve süreci hızlandıran olayların alt yapısına çok fazla değinilmemiştir. Çalışmanın bu hususta katkı sağlayacağı düşülmektedir.

\subsection{Yüzyılın Iilk Yarısında Trakya Şehirleri}

Bizans şehirlerinin geneli; etrafı surlarla çevrili, kale-şehir (castrum/ordugâh) olarak bilinen, daha çok askerî nitelikleriyle ön plâna çıkmış karakteristik Ortaçağ şehirleriydi. Güçlü surlarla çevrili olan bu şehirler olası bir saldııı anında halkın toplanacağı, kendilerini güvende hissedecekleri yerlerdi. Ortaçağ'da kale duvarlarılla tahkim edilmemiş kent âdeta yok gibiydi. ${ }^{19}$ Bizans coğrafyasında XIII. yüzyıla ulaşan çoğu manastır, saray, köprü, su kemeri, hamam gibi mezkûr kaleler de İmparator I. lustinianos zamanından kalmıştı. ${ }^{20}$ Trakya kentleri tıpkı Anadolu'daki benzerleri gibi güçlü surlarla çevrilmişti. Edirne, Roma castrumu iken bu kalenin içinde gelişmiş bir Bizans şehrine dönüşmüştü. ${ }^{21}$ Dimetoka şehri yine l. lustinianos zamanında yıkılan surların yeniden inşasıyla ihyâ edilmiş bir şehirdi. Keza güneydeki Gelibolu Kalesi de İmparator I. lustinianos tarafından tamir ettirilmiş olup kale zamanla önemli bir liman ve ticaret merkezi hâline gelmişti. ${ }^{22}$

XIII. yüzyılın sonlarına doğru Batıdan gelen tehlikelerin önlenmesi ve Konstantinopolis'in savunmasının artırılması için bu bölgedeki kentlere daha çok ihtimam gösterilmişti. ${ }^{23}$ Konstantinopolis'e batı cihetinden gelebilecek saldırılar karşısında yukarıda da zikredildiği üzere özellikle Meriç Nehri hattı doğal bir sınır olarak görüldüğünden bu hat boyunca belli şehirler tahkim edilmişti. Güçlü surlara sahip olan bu kentler Bizans'ın sınır boylarındaki askerî üs vazifesini görmekteydiler. XIII. yüzyılın sonlarından itibâren olmak üzere yaşanan gelişmeler

18 Nicol, a.g.e., s. 270.

19 Henry Pirenne, Ortaçağ Avrupası'nın Ekonomik ve Sosyal Tarihi, çev. Uygur Kocabaşoğlu, İstanbul 2009 , s. 66.

20 I. Iustinianos zamanında imparatorluğun en uzak köşelerinde dahi kaleler ve kiliselerin yanı sıra pek çok manastır, saray, köprü, sarnıç, su kemeri gibi yapılar inşa edilmiştir. Bkz. Alexander A. Vasiliev, Bizans Imparatorluğu Tarih, çev. Tevabil Alkaç, İstanbul 2016, s. 228.

21 Semavi Eyice, “Kale”, DIA, C. XXIV, İstanbul 2001, s. 234.

22 Feridun M. Emecen, "Gelibolu”, DIA, C. XIV, İstanbul 1996, s. 1.

23 Nicol, a.g.e., s. 104. 
dikkate alındığında özellikle XIV. yüzyıın başlarında ülkenin batı sınırlarının korunmasında Dimetoka, kuzey sınırlarının denetim altına alınmasında ise Edirne'nin âdeta Bizans'ın savunma üssü olduğu açıkça görülmektedir.

Bu şehirlerin askerî üs ya da güçlü surlara sahip olmasının yanında Bizans'ın siyasî hayatında da ayrıca önem taşıdıkları dikkat çekmektedir. Özellikle XIII. yüzyılın sonlarından itibâren mezkûr kentler müstakil idâre oluşturmak isteyen müşterek imparator adaylarının âdeta propanganda merkezi hâline gelmişlerdir. Dede-torun Andronikos'lar arasındaki mücadele esnasında varılan anlaşmaya göre II. Andronikos Palaiologos (1282-1328) Konstantinopolis'te, III. Andronikos Palaiologos (1328-1341) ise Hadrianopolis'te ikame etmeyi kararlaştırmışlardı (6 Haziran 1321). Daha sonra ise III. Andronikos, Dimetoka'da kalmayı tercih etti. ${ }^{24}$ Yine ikinci iç savaş döneminde Bizans başkomutanı ve imparator nâibi olan loannes Kantakuzenos 26 Ekim 1341'de Dimetoka'da Trakya soylularının desteğiyle imparatorluğunu ilân etmiştir. ${ }^{25}$ Ancak burada bir taç giyme töreni gerşekleşmemişti. Bizans geleneğinde bir kişinin resmî olarak imparator ilân edilebilmesi için taç giyme töreninin kilisede patrik tarafından gerçekleştirilmesi gerekiyordu. Kudüs Patriği'nin bir süre önce Konstantinopolis'ten kaçıp I. loannes Kantakuzenos'a sığınması kendisine bir patrik elinden taç giyme fırsatını vermiş ve nihayetinde 1346 yılında Kudüs Patriği'nin elinden Edirne'de törenle tacını giyip resmen imparator olmuştu (1346-1354). ${ }^{26}$ Böylece artık Edirne, müşterek imparatorluk makamı olarak Konstantinopolis'in de rakibi hâline gelmiştir. Gerek Dimetoka gerekse Edirne şehirleri başkentle olan ilişkileri bağlamında yönetim organizasyonu içerisine dâhil olup bir şekilde kendilerine yer bulmuşlardır. Hem başkentle sıkı ilişkiler içinde olmaları hem de savunma hattında yüklendikleri misyonalar sebebiyle çatışmaların ya da saldırıların etkilerini de oldukça derinden hissetmişlerdir. Trakya'nın iç kısmında bulunan Edirne ve Dimetoka kentlerinin yanı sıra bölgenin güneyinde, Çanakkale yönünden İstanbul'u hedef alan tehlikelerin önleneceği yer olarak düşünülen Gelibolu şehri de ayrıca dikkat çekmekteydi. ${ }^{27}$ Burası hem Ege hem Çanakkale hem de Marmara Denizi'nin kontrol altında tutulmasında oldukça stratejik bir yer olup imparatorluk için hayatî önem taşıyan Avrupa topraklarının savunulmasında Trakya'nın kilidi olarak görülmekteydi.

İmparatorluk için önemli görevler üstlenen Trakya şehirleri XIV. yüzyılın başlarından itibâren arda arda gelen felaketler zinciriyle karşı karşıya kalmışlardır. Bulgar Krallığı'nın kuzeyden Edirne sınırlarını zorlamaya başladığı sıralarda ${ }^{28}$ güney yönünde de ayrı bir tehlike baş göstermiştir. Bizans idâresinin Batı Anadolu'daki Türkmen ilerleyişini durudurmak için Anadolu'ya sevk ettikleri Katalan birliklerinin kontrolden çıkması sebebiyle bu birlikler 1304

\footnotetext{
24 Nicol, a.g.e., s. 194-195.

25 Nicol, a.g.e., s. 194-235.

26 Tacını beş patrikten birinin elinden giymiş olması onun gerçek imparator olup olmaması tartışmasını da nihayete erdirmiştir. Bu hususta bkz. Nicol, a.g.e., s. 234-254.

27 Nicol, a.g.e., s. 299.

28 Nicol, a.g.e., s. 164.
} 
kışında Magnesia (Manisa) üzerinden Çanakkale Boğazı kıyısındaki Lampsakos (Lapseki)'a burdan da Gelibolu'ya ulaşmışlardır. ${ }^{29}$ Gelibolu'da konuşlanan Katalan birlikleri Anadolu'daki hizmetlerine karşılık ayarı düşük para aldıklarını bahane ederek Gelibolu ve çevresini yağmalamaya başladılar. Bizans idâresi Katalanları durdurmak için doğrudan liderleriyle görüşme yoluna gitmiştir. ${ }^{30}$ Trakya'daki eylemlerini durdurmak ve Anadolu'da imparatorluk için yaptıkları vazife karşılığında yüklü ücretler talep eden Katalan lideri Roger de Flor, II. Andronikos'un en büyük oğlu ve ortak imparator olan IX. Mikhael'in girişimiyle ikametgâhı olan Edirne'ye davet edilerek burada kurulan bir tertiple etkisiz hâle getirilmiştir. ${ }^{31}$ Ancak bu plân işe yaramanın aksine Trakya'da daha büyük meselelerin başlangıcını teşkil etmiştir. Nitekim Gelibolu'da konuşlanmış Katalan birlikleri liderlerinin öcünü almak üzere Trakya'yı yağmalamaya başlamışlardır. Gelibolu ve çevresini İspanyol toprağı olarak ilân ettikten sonra halkının büyük kısmını öldürüp geri kalanı ise köle olarak ele geçiren Katalanlar, Gelibolu'yu iki buçuk yıl boyunca devletlerinin başkenti yapmışlardır. ${ }^{32}$

Bundan sonra Trakya şehirleri tümden Katalanların tehdidi altına girmiş ve onları Trakya'da durdurmak görevi ise IX. Mikhael'e verilmiştir. Alanlarla birlikte Türk yardımcı kuvvetlerinden oluşan Bizans ordususu 1305 yılı Haziran'ında Rhaidestos (Tekirdağ) yakınındaki Apros (İnecik)'ta Katalanlara karşı ard arda giriştiği iki çatışmada da hezimete uğramıştır. Hemen hemen bütün ordusunu yitiren ve canını kurtarmayı dahi güçlükle başaran IX. Mikhael, Dimetoka'ya sığınmıştı. ${ }^{33}$ Bizans ordusunun dağılmasının ardından ordu içindeki Türk gruplar (Türkolopoller) ise Katalanların safına geçmişlerdir. ${ }^{34}$ Diğer yandan Apros'tan ayrılan Katalanlar sahile inerek Trakya'yı gözetlemek üzere üs olarak kullanmayı plânladıkları Tekirdağ'ı kuşatmışlardır.

Tekirdağ Kuzey Marmara sahil yayında Gelibolu-İstanbul arasında küçük bir liman kenti olup buna karşın oldukça fonksiyonel bir kenttir. Edirne ile İstanbul'a eşit mesafede olup her iki şehirle irtibatı üst seviyedeydi. Ayrıca burası başkent İstanbul'un gıda temininde önemli bir transfer merkezi olup Trakya topraklarından hasıl olan hububat ve diğer besin maddelerinin başkent İstanbul'a sevkinde öneme sahipti. ${ }^{35} \mathrm{Bu}$ sebeple XI. yüzyıldan itibâren Bizans idâre-

29 Nicol, a.g.e., s.163. Batı Anadolu'daki Katalan tahribatını önlemek ve ayrıca Bulgar Kralı'nın İstanbul'a olası saldırılarını durdurmak üzere imparator II. Andronikos, Katalan lideri Roger de Flor'a Gelibolu'ya geçmesi, oradan tüm kuvvetleriyle İstanbul'a gelmesi hususunda tâlimât göndermiştir. Bkz. Yusuf Ayönü, a.g.e., s. 50-52. Bu suretle Katalan birlikleri Gelibolu'ya gelip yerleşmişlerdir.

30 Yusuf Ayönü, a.g.e., s. 54-57.

31 Alexander A. Vasiliev, a.g.e., s. 678.

32 Şerif Baştav, "Osmanlı İmparatorluğu'nun Kuruluşu Esnasında Bizans ve Avrupa”, Belleten, LXVIII, S. 251, s. 19. Ayrıca bkz. Nicol, a.g.e., s. 165.

33 Nicol, a.g.e., s.166.

34 Yusuf Ayönü, “Osmanlılardan Önce Rumeli'de Türkler (1305-1313)”, Tarih Incelemeleri Dergisi, Cilt/XXI, S. 2, İzmir, Aralık 2006, s. 21.

35 Bizans döneminde Rhaidestos/Rodoscuk İskelesi'nin bölgedeki fonksiyonu ve İstanbul'a ürün sevkiyatı hususunda bkz. Hacer Ateş, “Kuzey Marmara'da Bir Liman Kentinde Ticaret: XVI. Yüzyılda Tekirdağ-Rodoscuk Limanı”, Trakya Üniversitesi Edebiyat Fakültesi Dergisi, Cilt: 3, sayı: 6, Temmuz-2013, s. 21-22, 27. 
cileri tarafından sıkı şekilde denetim altında tutulmaktaydı. ${ }^{36}$ Şehrin bir besin deposu olması ise Katalanlar için avantajlı bir durum yaratmıştır. Zîra Katalanların 1308'de Trakya'yı terk ederek Rodoplara çekilmesindeki etkenlerin başlıcası Trakya topraklarında artık tüketecekleri kaynakların yetersiz kalması idi. ${ }^{37}$ Şehir bu bakımdan beklentilerini yüksek oranda karşılayabilirdi. Ayrıca burası hem İstanbul hem de Gelibou'ya eşit mesafedeydi. Tüm bu özelliklere sahip Rhaidestos'un Katalanlar için Gelibolu'ya alternatif bir üs olarak düşünüldüğü açıktır.

Rhaidestos Kalesi'nin kuşatıldığını öğrenen imparator buradaki halkı kurtarmak üzere İstanbul'dan iki triere (trirem/üç sıra kürekli gemi) yollamıştır ${ }^{38}$. Böylece halk kentten uzaklaştırılarak sadece savunma yapabileceklerin kalması plânlanmıştır. Ancak bu girişimin neticesiz kalması üzerine halkın çoğu teslim olurken kaleden kendi çabalarıyla uzaklaşmayı başaranlar hayatta kalabilmiştir. Katalanlar geri kalan Rhaidestos'un tüm halkını erkek, kadın ve çocuklar ayırt etmeksizin kılıçtan geçirmişlerdir. Halk yok edilip kent boşalınca yeni ordugâhları başta olmak üzere buraya taşınmışlardır. ${ }^{39}$ Bu süreçte Gelibolu ise Trakya'yı yağmaladıkları esnada ele geçirdikleri esirleri satmak üzere köle pazarı hâline getirilmiştir.40 1304-1307 yılları arasında Gelibolu'yu merkez üs edinip tüm Trakya'yı özellikle Kuzey Marmara kıyılarını İstanbul kapılarına kadar talan eden Katalanlar, Gelibolu'daki birliğin kumandanı Ramon Muntaner önderliğinde bölgeden ayrılırken başta Gelibolu ve Madytos (Maydos/Eceabat) olmak üzere hâkim oldukları tüm kaleleri yakıp tahrip ettiler. ${ }^{41}$ Trakya'yı tamamıyla yağmaladıktan sonra 1307 sonbaharında Rodoplara çekilerek akınlarını orada devam ettirmişlerdir. ${ }^{42}$

Katalanların çekilmesiyle Trakya halkının üstündeki baskı biraz hafiflemiş fakat bu esnada şehirlerin çoğu tahrip olurken tarım arazileri de yakılıp yağmalanmıştı. Hatta Katalanların ilerleyişi önlenemez bir hâl alınca İmparator II. Andronikos başkente yürüme ihtimâllerini göz önünde bulundurarak yol üzerinde iâşe temin etmelerini önlemek amacıyla olsa gerek Selymbria (Silivri) ile Konstantinopolis arasındaki bütün arazinin boşaltılmasını ve ürünlerin yakılmasını emretmişti. ${ }^{43}$ Bu yerlerde meskûn olan halk ise yaşanabilecekler karşısında canlarını kurtarmak için çözümü güçlü surlarla çevrili Konstantinopolis'e sığınmakta bulmuşlardır. Trakya'nın çoğu yerinde benzer durumların yaşanmasıyla başkentin gıda ihtiyacını temin etti-

36 İmparatorluğun iâşe politikasındaki değişiklikten sonra VII. yüzyıldan itibâren Konstantinopolis'e buğday Bitinya, Trakya ve Bulgaristan topraklarından gelmekteydi. Bu süreçte büyük sevkiyatların yapıldığı Rhaidestos devlet denetiminin üst düzeyde olduğu bir liman kenti hâline gelmiştir. Bkz. Michael Kaplan, "İmparatorluğun Midesi”, Konstantinopolis 1054-1261, ed. Alain Ducellier-Michel Balard, çev. Can Belge, İstanbul 2002, s. 90.

37 Nicol, a.g.e., s. 167

38 Georges Pachymeres, Bizanslı Gözüyle Türkler, çev. İlcan Bihter Barlas, İstanbul 2009, s. 107.

39 Gelibolu'da Muntaner idâresinde küçük bir birlik olan Katalanlar Gelibolu'daki kadın ve çocuklarını da yanlarına alarak İstanbul'a daha yakın ve Trakya içlerine düzenleyecekleri akınlar için daha elverişli konuma sahip olan Rhaidestos ve Panion (bugünkü Tekirdağ-Barbaros) şehirlerine yerleştiler. Bkz. Yusuf Ayönü, Katalanların Anadolu, s. 66.

40 Nicol, a.g.e., s.166.

41 Yusuf Ayönü, Katalanların Anadolu, s. 87.

42 Ostrogorsky, a.g.e., s. 456.

43 Nicol, a.g.e., s. 167. 
ği yanı başındaki tarım arazileri kullanılmaz hâle gelirken arazilerdeki köylüler ve çiftçiler de yerlerinden olmuşlardır. Bu durum kırsal alanda nüfus azalmasını da beraberinde getirmiştir.

Katalan saldırılarıyla büyük tahribata uğrayan Trakya şehirlerinde sükûketin sağlanmasına fırsat kalmadan yeni bir tehlike belirmiştir. Bölge bu kez de Batı Anadolu beyliklerinin hedefi hâline gelmiştir. Bu sırada özellikle Gelibolu'nun hemen karşı sahilindeki Karesi Beyliği ciddi bir tehdit unsurudur. Yahşi Bey'in 1341'de Gelibolu seferi büyük telâşa sebep olduysa da, I. loannes Kantakuzenos'un girişimleri bu atağı akamete uğratmışıı. ${ }^{44}$ Batı Anadolu'nun en önemli beyliklerinden olan Aydınoğulları ise Bizans taht mücadelelerinin ikinci evresinde Kantakuzenos'un müttefiki olarak Trakya topraklarına geçmişlerdir. ${ }^{45}$ Umur Bey'in denetimindeki müttefik kuvvetler bu esnada sadece Trakya'nın kırsal alanında değil Selânik sahillerinden başlayarak Gelibolu-Silivri arasındaki Trakya sahillerini de talan etmişlerdir. Bu durum Trakya halkında büyük öfke ve tepkilere yol açmışıı. ${ }^{46} 1352$ yılında diğer bir müttefik saldırısına bu defa Edirne mâruz kalmıştı. İmparator V. loannes Palaiologos (1341-1391) karşısında Kantakuzenos'un oğlu Mattheos'un hâkimiyetini güçlendirmek üzere müttefiki olan Orhan Bey, oğlu Süleyman Paşa idâresindeki Osmanlı kuvvetlerini Trakya'ya göndermiştir. Edirne'de halk Kantakuzenos Ailesi'nin yönetimine tepki olarak şehrin kapılarını V. Ioannes Palaiologos'a açmıştır. Süleyman Paşa ile bir araya gelen Kantakuzenos ise V. loannes Palaiologos'u destekleyen Edirne halkını cezalandırmak üzere Edirne ve yakınındaki yerleri yağmalamaları için Osmanlı kuvvetlerine izin vermişsir. ${ }^{47}$ Osmanlı birliklerinin sayısının yaklaşık 10.000-12.000 kişi olduğu düşünüldüğünde Edirne ve çevresinde meydana gelen tahribatın ne derece büyük olduğu tahmin edilebilir.

Trakya'da saldırıların ve iç savaşların eşlik ettiği yıkımların âdeta sonu gelmemektedir. 1344 yilında Trakya kıyıları ile iç kesimlerinde hissedilen şiddetli deprem can kaybıyla birlikte oldukça ciddi hasarlara da yol açmıştır. Bizans kaynakları bu hususta önemli kayıplar olduğu hakkında bilgi vermektedirler. Özellikle Kuzey-Batı Marmara sahil yayında Gelibolu yakınlarında Ganos (Gaziköy) ve Hora (Hoşköy) bölgesinde bulunan surlar ile evlerin büyük kısmı yerle bir olurken 300'den fazla kişinin bu yıkıntıların altında kaldığı zikredilmektedir. ${ }^{48}$ Ancak 1354 yılındaki Gelibolu depreminin yarattığı etkiler bir öncekinden daha yıkıcı olmuştur. Büyük can kayıplarının yaşandığı depremde Gelibolu savunma sistemin temeli olan surlar da yerle bir

44 Zerrin Günal Öden, Karası Beyliği, TTK Yayınları, Ankara 1999, s. 43-44. Karesi ümerâsının daha önce Katalanlarla birlikte Trakya bölgesine geçtiği bilinmektedir. Katalanlarla birlikte Trakya'daki faaliyetleri için bkz. Yusuf Ayönü, "Osmanlılardan Önce", s. 20-23.

45 Umur Bey'in daha 1330'lardan itibâren gerek Ege Denizi'nde adalar üzerine gerekse Bizans'In Avrupa topraklarına yönelik fetih hazırlıklarında olduğu konusunda bilgiler mevcuttur. Umur Bey 1331'de Gelibolu üzerine bir sefere çıkmıştır. Yine 1332 yılında Türklerin Negrepont (Eğriboz) üzerine akınlarından da bahsedilmektedir. Bkz. Himmet Akın, Aydınoğulları Tarihi Hakkında Bir Araştırma, Ankara Üniversitesi Yayınları, No. 60, Ankara 1968, s. 35.

46 Bizans kaynaklarında saldırı, yağma ve talan vesilesiyle tahrip olmuş bölgeler "iskit Çölü" olarak tanımlanıyordu. Bu tâbir Katalan ve Türk saldırılarına mâruz kalan tüm topraklar için kullanılmışıı. Bkz. Nicol, a.g.e., s. 170.

47 Ostrogorsky, a.g.e., s. 186-187.

48 Esin Ozansoy, "Bizans Kaynaklarına göre 1200-1453 Depremleri”, Tarih Boyunca Anadolu'da Doğal Âfetler ve Deprem Semineri, 22-23 Mayıs 2000, İstanbul 2001, s. 15. 
olmuştur. Daha sonraki gelişmeler ise Gelibolu'nun Bizans'ın elinden çıkmasıyla neticelenecektir. Bölgede meydana gelen muharebeler, çatışmalar ve doğal afetler sonucunda Trakya şehirlerinin büyük ölçüde nüfus kaybına uğradığı anlaşılmaktadır. Bununla birlikte geri kalan nüfusun yaklaşık beşte biri de 1348'de Asya'da başlayıp Karadeniz üzerinden Avrupa topraklarına yayılan veba salgını yüzünden hayatını kaybetmiştir. ${ }^{49}$ XIV. yüzyılın başlarında Katalan meselesiyle başlayan felâketler zinciri yüzyılın ikinci yarısına kadar devam etmiş, Trakya kentleri ve halkı bu zorlu süreçte oldukça yıpranmıştır.

\section{1. Osmanlıların Trakya Tarafına Geçişi}

Osmanlıların Trakya şehirleri ile tanışmaları yukarıda da ele alındığı üzere Bizans'ın ikinci iç savaş yılları olarak bilinen VI. Kantakuzenos ile V. Ioannes Palaiologos arasındaki iktidar mücadeleleri esnasında başlamıştır. Ancak Osmanlılardan daha önce Batı Anadolu'daki Türk Beyliklerinin Trakya taraflarında boy gösterdiği gerek yağma gerekse bölgeyi tanımak adına sık sık akınlar yaptığı bilinmektedir. 1300'lü yıllarda Osman Bey'in Bitinya taraflarında ilerlediği esnada Batı Anadolu'da diğer Türkmen Beylikleri de Bizans aleyhine sınırlarını genişletmekte idiler. Karesi, Saruhan, Aydın, Menteşe beylikleri bölgede oldukça etkindiler ve Ege ile Trakya topraklarına devamlı surette akınlar düzenlemekteydiler. ${ }^{50}$ Bitinya bölgesini kısa zaman içinde idâresine alan Osmanlılar ise pek çok kıyı kenti ve kasabasını ele geçirip Marmara sahillerine ulaşmışlar, Üsküdar'a kadar olan Bizans topraklarını ele geçirerek Bosporus (İstanbul Boğazı)'a varmışlardı. Orhan Bey'in bundan sonraki plânı ise Çanakkale Boğazı'nı da ele geçirerek Bizans'ın Anadolu ile olan irtibatını tamamen ortadan kaldırmak yönünde olacaktır.

Osmanhıların hedef bölgesi olan Çanakkale Boğazı'ndaki Karesi Türkmenleri Asya kıyısını denetim altında tutarak Trakya'ya akınlar düzenlemekteydiler.. ${ }^{51}$ Osmanlı Beyliği ilk adımda Marmara sahillerine ve Ege'ye açılan bir beylik olan Karesioğulları ile dikkat çekici bir rekabet ve siyasetin içine girmiş ise de onların denizcilik tecrübelerinden yararlanmaları oldukça yerinde bir karar olmuştur. ${ }^{52}$ Karesi Beyleri arasındaki anlaşmazlıklar Orhan Bey'i hedeflerine ulaştırmıştır. Nitekim Demirhan ve Dursun Bey arasındaki iktidar mücadelelerinde Hacı İlbey ve Karesi ümerâsı Dursun Bey'i destekleyerek bu hususta Orhan Bey'den yardım istemiş, buna karşılık beyliğin bazı stratejik bölgelerini de ona vermeyi teklif etmişlerdi. ${ }^{53}$ Yaşanan gelişmeler neticesinde 1345 yılında yaklaşık 40.000 atlı askeri ve deniz gücü ile birlikte Karesio-

49 Şerif Baştav, “Osmanlı İmparatorluğu'nun Kuruluşu”, s. 51.

50 1320'lerde Batı Anadolu'da güçlü bir bey hâline Saruhan Bey özellikle denizlerde zaman zaman komşuları olan Aydın ve Menteşe beyleriyle ortak hareketler düzenlemişlerdir. 1331 yılında ise Aydınoğlu Umur Bey ve Saruhanlı birlikleri Gelibolu üzerine sefere çıkmışlardır. Bkz. Feridun M. Emecen, "Saruhan Oğulları Beyliği", Anadolu Beylikleri El Kitabı, ed. Haşim Şahin, Ankara 2016, s. 144-145.

51 Elizabeth A. Zachariadou, “Karesi ve Osmanlı Beylikleri: İki Rakip Devlet”, Osmanlı Beyliği (1300-1389), ed. Elizabeth A. Zachariadou, çev. Gül Çağlı Güven vd., İstanbul 1997, s. 243.

52 Osmanlı-Karesi rekabeti hususunda bkz. Feridun M. Emecen, Ilk Osmanlılar ve Batı Anadolu Beylikler Dünyası, İstanbul 2010, s. 50-51.

53 Karesi topraklarındaki iktidar mücadelelerinde oldukça önemli rol oynayan vezîr Hacı İlbey'in Orhan Bey ile iletişime geçerek beyliğin Osmanlı nüfuzuna geçmesinde büyük etkisi olduğu görülmektedir. Bkz. Zerrin Günal Öden, a.g.e., s. 50-52. 
ğulları artık Osmanlılara bağlanmışlardı. ${ }^{54}$ Karesi topraklarının Osmanlılara ilhakı Trakya'ya giden yolu açmakla birlikte akabinde cereyân eden olaylar da Trakya'nın fethini hazırlamıştır. Karesi Beyliği'nin ilhakı neticesinde Osmanlılar Bizans ile bu kez Çanakkale'de karşı karşıya gelmişler ve böylece Osmanlı Beyliği ile Bizans İmparatorluğu arasındaki sınırların uzunluğu da neredeyse iki misline çıkmıştır. Hâl böyle iken Saruhan, Aydın, Menteşe gibi beyliklerin imparatorlukla herhangi bir sınır teması kalmamıştı. ${ }^{55}$

XIV. yüzyılın ortalarına doğru Bizans'ın içinde bulunduğu siyasî şartlar Osmanlıların karşı yakaya geçişi hususunda âdeta fırsat yaratmıştır. Nitekim 1341 yılında İmparator III. Andronikos'un ölümü birlikte Bizans taht kavgalarında ikinci bir dönem başlamıştır. ${ }^{56} \mathrm{III}$. Andronikos'un ölümünden sonra henüz dokuz yaşındaki oğlu V. Ioannes Palaiologos (1341-1391) imparator olmuş ve daha III. Andronikos hayatta iken devleti fiîlen idâre eden Megas Domestikos (Ordular Komutanı) loannes Kantakuzenos ölen imparatorun en yakın dostu sıfatıyla niyâbet üzerinde hak iddia etmiştir. ${ }^{57}$ Ancak Imparatoriçe Anna ve başkent ileri gelenleri Kantakuzenos'un nâibliğini kabul etmemişlerdir. Bu taht krizi esnasında Stefan Duşan Makedonya'yı kuşatmış, Bulgarlar ise kuzeyden sınırları tehdit etmeye başlamıştır. Kantakuzenos, ordu komutanı sıfatıyla asayişi sağlamak ve sınırları muhafaza etmek üzere imparatorluk ordusuyla birlikte Trakya'ya geçmiş ardından Trakya soylularının desteğiyle 26 Ekim 1341 tarihinde Didymoteikhon'da imparator ilân edilmiştir. ${ }^{58}$ Bundan sonra yaşananlar Kantakuzenos ve Palaiologos aileleri arasında bir iç savaşa dönüşmüş, her iki grup iktidarı tek başına ele alabilmek adına çeşitli ittifaklar içine girişmişlerdir.

Kantakuzenos ilk önceleri III. Andronikos zamanındaki tanışıklı̆a binaen Sırp Kralı Stefan Duşan'dan yardım talep etmiş ancak Duşan'in taraf değiştirmesiyle Türkler onun beklentilerine cevap vermişlerdir. Kantakuzenos Selânik'te patlak veren Zealotlar Ayaklanması üzerine Dimetoka'dan ayrılmış, geri döndüğünde ise kentin imparator V. loannes Palaiologos'un İstanbul'dan gönderdiği kuvvetlerce kuşatıldığıı görünce şehre giremeden geri dönmek zorunda kalmıştır. İşte bu sıralarda Aydınoğlu Umur Bey ile geçilen irtibat neticesinde Umur Bey 1342 kışında donanmasıyla Meriç Vadisi boyunca ilerleyip Didymoteikhon'u (Dimetoka) kurtarmaya gelmiştir. ${ }^{59}$ 1342-1345 yılları arasında Umur Bey'in müttefiki Kantakuzenos'a yardım amacıyla

54 İlhak tarihi konusunda muhtelif görüşler bulunmakla birlikte 1345-1346 yılları üzerinde ittifak edilmektedir. bkz. Zerrin Günal Öden, a.g.e., s. 56-60. Osmanlı kuvvetlerinin Süleyman Paşa komutasında Trakya'ya ilk geçişlerinden önce ilhakın gerçeklemiş olması gereklidir. Zîra Osmanlıların Trakya'ya ilk geçişleri 1348'de vuku bulmuştur.

55 Hüseyin Dağtekin, “Türkleri Boğazlar Bölgesi'ne Çeken Gerçek Sebepler”, AÜDTCF Dergisi, XIX/3-4, Ankara 1962, s. 177.

56 Nicol, a.g.e., s. 229-234.

57 i. Hakkı Uzunçarşılı, Osmanlı Tarihi, C. I, Ankara 1988, s. 155; Ostrogosrky, a.g.e., s. 470.

58 Ostrogorsky, a.g.e., s. 470-471; Nicol, a.g.e., s. 235-243.

59 Nicol, a.g.e., s. 239-243. Umur Bey Dimetoka'da bulunduğu esnada buradan hareketle Christoupolis ve Ferecik taraflarına akınlar düzenlemiş ve 1343 yılında hava koşullarının elverişsizliği sebebiyle tekrar İzmir'e geri dönmek zorunda kalmıştır. Bkz. Feridun M. Emecen, “Aydınoğlu Umur Bey: Kısa Bir Biyografi Denemesi”, Uluslararası Batı Anadolu Beylikleri Tarih, Kültür ve Medeniyet Sempozyumu -I- Aydınoğulları Tarihi (Bildiriler), TTK Yayınları, S. 4, Ankara 2013, s. 53-54. 
beş kez Trakya bölgesine geçtiği bilinmektedir.60 Tahmin edileceği üzere Dimetoka tarafları bu süreçte Umur Bey ve adamlarının uğrak yeri hâline gelmiştir. Umur Bey'in İzmir bölgesindeki Lâtinlerle mücadeleye yoğunlaşması ise Kantakuzenos'u yeni müttefikler aramaya sevk etmişsir. ${ }^{61}$ Kantakuzenos, Orhan Bey'le irtibata geçip Osmanlı askerî gücünden istifâde etmek istemiş ve bu teklif Osmanlıların tıpkı Aydınoğulları gibi ilk kez müttefik sıfatıyla Trakya coğrafyasına geçmesine vesile olmuştur. ${ }^{62}$ Nitekim Karesi topraklarının ilhakından sonra Osmanlı poltikalarının temelini buradan hareketle Trakya'ya geçmek fikri oluşturmaktadır.

Orhan Bey'in ordusu asker sayısı bakımından oldukça kalabalık ve yetenekli muhariplerden oluşmaktaydı. Kantakuzenos ise onları Pelekanon Savaşı'nda yakından tanıma fırsatı bulmuştu. Kantakuzenos-Osmanlı ittifakı 1346'da Kantakuzenos'un kızı Theodora ile Orhan Bey'in evliliği neticesinde daha da pekişmiştir. ${ }^{63}$ Orhan Bey'le ittifaktan bir yil sonra Kantakuzenos, maiyetindeki 1.000 kişilik kuvvetle İstanbul'a girip sarayı kuşatmış ve genç imparatorun ortağı olarak tahta oturmuş̧tur (8 Şubat 1347).64 1342'de başlayan Zealotların isyanı ile karışıklığın hüküm sürdüğü Selânik'in 1347'de Stefan Duşan tarafından kuşatılmasıyla Kantakuzenos damadı ve müttefiki olan Orhan Bey'den yardım istemiştir. Orhan Bey, oğlu Süleyman'ın idâresindeki 10.000 kişilik bir orduyu yardıma göndermiştir. Süleyman Paşa karşı yakaya geçmiş ancak Christoupolis (Kavala)'ten öteye gidememiştir. Bununla birlikte Osmanlı kuvvetleri Teselya bölgesini yağmalayarak geri dönmüştür. ${ }^{65}$ Böylece Süleyman Paşa Trakya harekâtının ilk adımını atmıştır.

Osmanlı kuvvetlerinin Trakya'ya ikinci geçişi yine Selânik meselesi sebebiyle olmuştur. Zealotlar, Konstantinopolis'ten gelecek hiç bir emre uymayacaklarını ve hatta şehri Sırplara teslim edeceklerini duyurduğunda bunu fırsat bilen Sırp Kralı Stefan Duşan Selânik'e bir ordu göndermiştir. Bu durum Zealotlarla Selânik halkının arasının açılmasına sebep olmuştur. Şehirdeki karışıklıktan istifade ederek Selânik'i tekrar başkent idâresine bağlamak isteyen Kantakuzenos yine Orhan Bey'den yardım istemiştir. Süleyman Paşa bu kez 20.000 askerle Trakya'ya geçmiştir. ${ }^{66}$ Bundan iki yıl sonra Süleyman Paşa üçüncü kez Trakya'ya geçmiş ve bu harekât önce Gelibolu'ya akabinde tüm Trakya'ya hâkim olmalarına imkân sağlamıştır. Üçüncü geçiş müşterek İmparator V. loannes Palaiologos'un, Kantakuzenos'un oğlu tarafından idâre edilen Edirne'yi kuşatması üzerine gerçekleşmiştir. V. Ioannes, Bulgar Kralı Alexander ve Sırp

60 Düsturnamei Enverî Medhal, s. 62.

61 İzmir'i savunmak üzere 1345'ten itibâren Lâtinlerle başlayan mücadeleler ve gelişmeler için bkz. Feridun M. Emecen, a.g.e., s. 242-243. Keza mezkûr dönem hakkında en önemli kaynaklardan biri olan Düsturnâme süreç hakkında detaylı bilgiler içermektedir. Bkz. Düstûrnâmei Enverî Medhal, s. 51-59.

62 Düstûrnâme'de 1330'lu yıllardan itibâren diğer denizci beylikler gibi Orhan Bey'in de hemen hemen her yıl Trakya'ya akınlar yaptığı bilgisi yer almaktadır, bkz. Düsturnamei Enverî Medhal, s. 33. Ancak bunun Trakya'nın Marmara sahilleri ile sınırlı olduğunu söylemek gerekir. Zîra o yıllarda Osmanlıların coğrafî açıdan Marmara Denizi'nin dışındaki denizlerle irtibatı bulunmamaktadır.

63 Bu izdivacın detayları hususunda bkz. Yahya Başkan, "Orhan Bey'in Bizans İmparatoru Kantakouzeneos'un Kızı Theodora ile Evliliği", Tarih Dergisi, sayl: 66 (2017/2), İstanbul 2017, s. 47-61.

64 Halil İnalcık, "Osmanlı Sultanı Orhan", s. 81.

65 Feridun M. Emecen, Ilk Osmanlılar ve Batı Anadolu Beylikler Dünyası, s. 67.

66 Nicol, a.g.e., s. 282. 
Kralı Stefan Duşan'dan yardım talep ederken, Kantakuzenos da Orhan Bey'den yardım alarak oğlu Matteos'un imdadına yetişmiştir. Orhan Bey'in, oğlu Süleyman Paşa komutasında gönderdiği 10.000-12.000 kişilik birlik sayesinde ilk önce Bulgarlar yenilmişler, kısa süre sonra da Sırplar bozguna uğratılmışlardır. Palaiolaogos ve Kantakuzenos aileleri arasındaki bu iç savaşın aslında Trakya'nın kapılarını Osmanlılara açtığı görülmektedir. ${ }^{67}$

Osmanlılar yavaş yavaş Trakya topraklarında kendi memleketleri gibi hareket etmeye başlamışlardı. ${ }^{68}$ loannes Kantakuzenos kendisine sağlanan yardım konusunda daha fazla kolaylık ve sürat elde edilebilmesi maksadıyla, 1352 yılında Gelibolu yakınındaki Çimpe Kale'sini Süleyman Paşa'ya geçici bir üs olarak vermiştir.69 Süleyman Paşa, Biga'ya sancak merkezine dönerken Gelibolu kuzeyinde küçük Tzympe (Çimpe /Cimbi) Kalesi'nde bir Osmanlı kuvveti bırakmıştır. Gregoras'ın verdiği ayrıntılara göre “Türkler orada aileleriyle gelip yerleşmiş olup bir kadı ve bir camileri vardı. İmparatordan ücret alan bir askerî koloni gibi idiler." "Süleyman Paşa bundan sonra Gelibolu Yarımadası'nda kalıcı olmak için harekete geçecektir. Bu aşamada Gelibolu'yu abluka altına almak üzere özellikle kuzey yönündeki kale ve yerleşimlerin ele geçirilmesi gerekli idi. Bu hususta fethedilen diğer bölgelerde olduğu gibi plânlı ve sistemli bir şekilde hareket edildiği anlaşılmaktadır.

Dönem hakkında bilgi veren Osmanlı kronikleri incelendiğinde Gelibolu'nun hangi noktadan sıkıştırılabileceği, her iki yakada karşılıkıı iletişimin hangi bölgelerden ve hangi vasıtalarla sağlanabileceği hususunda Ece Bey, Gazi Fazıl ve Süleyman Paşa'ın uzun süre istişâre ettikleri anlaşılmaktadır. Ece Bey ve Gazi Fazıl'ın öncülüğünde keşif amaçlı Kemer Limanı'ndan hareketle Cimbi taraflarına geçildikten sonra uygun koşullar sağlandığında Cimbi Hisarı ele geçirilmiştir.71 Buranın kadın erkek tüm halkına iyi muâmele edildiği, onlara istimâlet verildiği ve hoşgörüyle davranıldığı anlaşılmaktadır. ${ }^{72}$ Bundan sonra ise yarımadanın kuzeyine doğru harekât sahası genişletilmiştir. Bu doğrultuda Süleyman Paşa ve kuvvetleri Aya-Şiline'yi (Aya-Şilonya), Od-Köklek (Balabancık) ve Eksamilye (bugün Eksamil) ${ }^{73}$ ile Akça-Burgos'u fethetmişlerdir. ${ }^{74}$

67 Ostrogorsky, a.g.e., s. 487-488.

68 Nicol, a.g.e., s. 298-299.

69 Çimpe Kalesi'nin yeri ve kalenin muhtelif isimleri hususunda bkz. Münir Aktepe, "Osmanlıların Rumeli'de İlk Fethettikleri Çimbi Kal'ası", Tarih Dergisi, C. I, S. 2, İstanbul 1950, s. 285-293.

70 Kantakuzenos, Süleyman'ın bu kaleyi 1351-1352'de Osmanlılarla savaş sürerken zorla ele geçirdiği ve imparatorun ısrarına rağmen terk etmediğini belirtmektedir. Hali İnalıık, "Batı Anadolu'da Yükselen Denizci Gâzi Beylikleri, Bizans ve Haçllar", Türk Denizcilik Tarihi, I, ed. İdris Bostan-Salih Özbaran, İstanbul 2009, s. 42.

71 Neşrî, s. 173-178; Âşıkpaşazâde, s. 123-124.

72 İstimâletin sözlük anlamı, "meylettirme, cezbetme, gönül alma" olup, Osmanlı kroniklerinde "halkı ve özellikle gayrimüslim tebaayı gözetme, onlara karşı hoşgörülü davranma, raiyyetperverlik" mânâsında kullanılmıştır. Fethedilen yerlerin halkına iyi davranma, onları himâye etme, dış düşmanlara karşı can ve mal güvenliğini sağlama, dinî konularda serbestiyet verme, vergi hususunda kolaylık gösterme Osmanlı istimâletinin başlıca unsurlarıdır. Mücteba Illgürel, "İstimâlet", DiA, C. XXIII, İstanbul 2001, s. 362.

73 Neşrî, s. 177.

74 Güvenilir çağdaş bir kaynağa dayandığı bugün kesin olarak meydana çıkan Enverî̉nin Düstûrnâme'sine göre Osmanılıarı Rumeli'ye geçip yerleşmeye teşvik eden Gelibolu Tekfuru Asen'in oğludur. Bu zat Müslümanlığı kabul etti ve Melik adını aldı. Onun teşvikiyle Lapseki'de bir gemi yapıldı ve asker sevk edilerek karşı sahilde önce baskınla Akça-Burgos zapt edildi, ardından Kozludere'ye 3.000 asker geçip Bolayır' aldı. Bkz. Halil Inalcık, “Osmanlı Sultanı Orhan”, s. 85-86. 
Fethin akabinde bölgenin ve kalelerin güvenliğini sağlamak amacıyla demografik bir değişikliğe ihtiyaç duyulduğu anlaşılmaktadır. Ele geçirilen hisarların sakinlerinden özellikle askerler aileleri ile birlikte Gelibolu'nun hemen karşı yakasındaki Karesi Sancağı'na geçirilip yerleştirilmiştir. Buna karşılık Karesi bölgesindeki savaşçı Türkmenler fethedilen yerlere nakledilerek iskân edilmiştir. Bundan sonra yapılacak harekâtlar ise Trakya'nın kilidi sayılan Gelibolu'yu ele geçirmek üzerine plânlanmıştır.

\section{2 Osmanlı Fethi Esnasında Trakya Şehirleri}

Süleyman Paşa'nın Çimpe'ye yerleşmesi ve çıkmak istememesi üzerine Kantakuzenos, Çimpe'nin teslim edilmesi için Süleyman Paşa'ya 10.000 hyperpyra tazminat vererek hisarın iadesi talebinde bulunmuştu. ${ }^{75}$ Ancak bu sırada Süleyman Paşa bir taraftan Trakya içlerine, diğer taraftan da Gelibolu yönünde akınlarda bulunuyorken aynı zamanda Gelibolu'yu da abluka altına alınmıştı ${ }^{76}$. Trakya'nın kilidi sayılan ve böylesi güçlü surlara sahip olan şehrin Osmanlılara kolay kolay teslim olmayacağı açıktır. Osmanlı fetih yöntemlerinden olan abluka altına alma taktiğinin burada da uygulandığı görülmektedir. ${ }^{77}$ Bitinya bölgesindeki kaleler uzun süren ablukalar neticesinde ele geçirilmişlerdi. Örneğin Bursa yaklaşık 10 yıl Osmanlı ablukasına direnmiş fakat sonunda teslim olmak zorunda kalmıştı. Kezâ, İznik şehri de uzun yıllar Osmanlı ablukasında kaldıktan sonra teslim olmaktan başka çare bulamamıştı. Bu minvalde Çimpe Kalesi ve ardından ele geçirilen Bolayır'ın Gelibolu şehrini kontrol ve baskı altında tutmak amacıyla kullanıldığı anlaşılmaktadır. Nitekim Gelibolu'nun fethi bahsinde Osmanlı kronikleri şehrin muhasara altına alındığını belirtmektedirler. ${ }^{78}$

Bolayır'da yerleşmiş olan Osmanlı kuvvetleri kuzey yönünde Gelibolu'nun Trakya'nın iç kesimleriyle olan irtibatını kontrol altına almıştır. Ayrıca Süleyman Paşa, Gelibolu Yarımadası'nın bu en dar berzahında İstanbul ve Trakya'dan gelebilecek Bizans kuvvetlerine karşı bir ucda gazilerin başına Ece Bey ve Gazi Fazıl, öbür ucda Evrenuz (Evrenos) olmak üzere iki serhad oluşturmuştu. ${ }^{79}$ Gelibolu güneyden yani karşı yakadan Karesi Sancağı tarafından kontrol edilmekteydi. Karesi Beyliği'nin 1345'te Osmanlı'ya bağlanmasıyla birlikte bölge Osmanlı idâresine katılmış ve artık bir Osmanlı sancağı olarak idârî teşkilât içinde yerini almıştı. Karesi gazilerinin daha Osmanlı idâresine geçmeden önce Trakya'ya yaptıkları akınlar neticesinde coğrafyayı çok iyi tanıyor olmaları Osmanlılar için oldukça avantaj sağlamıştır. Böylece kuzey ve güney yönünde her iki taraftan sıkıştırılan Gelibolu'nun başkent Konstantinopolis ile bağlantısı da kesilmiştir.

75 Nicol, a.g.e., s. 299.

76 Feridun M. Emecen, “Gelibolu”, s. 1.

77 Eski Türk devletlerinde de tercih edilen bu kuşatma taktiği Osman Bey ve ondan sonra gelenler tarafından da kullanılmıştır. Müstahkem kalelerin kolayca düşmesini sağlamak amacıyla, önce kalenin bağlı olduğu bölge fethedilmek suretiyle dişarı ile her türlü ilişkisi kesilerek kolayca alınabilmesi hedeflenmiştir. Bkz. Sevim- Yücel, a.g.e., s. 241.

78 Âşıkpaşazâde, s. 124; Neşrî, s. 177.

79 Halil İnalcık, Rûhi Tarihi'nden naklen dönem hakkında önemli bilgiler vermektedir. Bkz. Halil İnalcık, "Batı Anadolu'da Yükselen", s. 44. 
Osmanlılar Gelibolu'yu yaklaşık iki yıla yakın abluka altında tutmuşlardır. 1354 depremi olmasa idi kent ne kadar abluka altında kalır ya da şehir halkı bu durumdan nasıl etkilenirdi tahmin etmek güçtür. Zîra uzun yıllar Osmanlı muhasarası altında kalan güçlü surlara sahip korunaklı Bitinya kentleri açlığın ve susuzluğun baş göstermesi neticesinde teslim olmaktan başka çare bulamamışlardı. Hatta Orhan Bey uzun yıllar kuşatma altında bulunan İznik'e girdiğinde şehir halkının bir kısmının açlıktan hayatını kaybettığini öğrenmekle birlikte kaleyi teslim almak için içeri girdiğinde vaziyeti bizzat görmüştür. ${ }^{80}$

Gelibolu muhasarasının sürdüğü yıllarda bölgede yaşanan gelişmelerin Osmanlıların lehine olduğunu söylemek gerekir. Bizans'ın destekçisi olan Venediklilerin o yıllarda en büyük rakipleri Cenevizlilerle savaş hâlinde olmaları Osmanlılara Gelibolu harekâtları esnasında zaman kazandırmıştır. ${ }^{81}$ Ayrıca İstanbul'un içinde bulunduğu genel durum deniz yolu ile herhangi bir yardımı da imkânsız kılmaktaydı. Her yönden iyice sıkışan şehrin kaderinin belirlenmesinde ise Mart 1354'de meydana gelen deprem önemli bir rol oynayacaktır. Osmanlı ve Bizans kaynakları meydana gelen deprem ve zelzelenin kentte meydana getirdiği tahribat hakkında önemli bilgiler vermektedirler. Deprem Trakya sahillerinde birçok şehir ve kaleyle birlikte Gelibolu ve etrafındaki kaleleri de yerle bir etmiştir. Merkez üssünün Gelibolu olduğu anlaşılan deprem 1-2 Mart 1354 tarihinde gece saatlerinde meydana gelmiştir. ${ }^{82}$

Deprem Marmara Denizi kıyıları boyunca Tekirdağ'dan başlayarak Eceabat'a kadar Gelibolu ve Trakya'nın diğer kısımlarında çok kuvvetli bir şekilde hissedilmiş ve buralarda büyük yıkımlara sebep olmuştur. ${ }^{83}$ Depremin hissedildiği coğrafyaya bakıldığında çok geniş bir alanı etkilediği anlaşılmaktadır. Bu şiddetli deprem İstanbul'da da etkili olmuş, kentin surları pek çok noktadan yıkılmış ve evlerin çoğu yerle bir olmuştur. ${ }^{84}$ Oldukça sağlam ve güvenli görülen Gelibolu surları bu şiddetli depremde ayakta kalmayı başaramamıştır. Nitekim Gelibolu iç kale, surlar ve hemen aşağısında bir limandan ${ }^{85}$ müteşekkil oldukça korunaklı bir şehir-

80 Âşıkpaşazâde, s. 119.

81 Halil İnalcık, "Osmanlı Sultanı Orhan", s. 88.

82 Bazı Bizans kaynaklarına göre deprem 1 Mart 1354 günü saat 19:30 sularında meydana gelmiştir, bkz. Esin Ozansoy, a.g.m., s. 15-16. Ancak depremin 1 Mart gecesi 02:00 saatlerinde yani ertesi günün ilk saatlerinde olduğuna dâir bilgi de mevcuttur, bkz. Şahin Kılıç, a.g.e., s. 262.

83 Esin Ozansoy, a.g.m., s. 15-16.

84 Kantakuzenos genel olarak depremin Trakya'daki etkilerinden söz ederek bilhassa Gelibolu'ya odaklanmıştır. Bununla birlikte İstanbul'da nasıl hissedildiği ya da kente etkilerinden söz etmemektedir. Ancak Nikeforos Gregoras bizzat görgü tanığı olarak depremin İstanbul'daki boyutunu ve oluşturduğu zararları dile getirmektedir. Bu hususta bkz. Esin Ozansoy, a.g.m., s. 15.

85 Osmanlı Devleti'nin ilk teşekküllü tersanesi 1390'da Yıldııım Bayezid tarafından Gelibolu'da Bizans'tan kalan tersanenin yerinde kurulmuştur. Bu dönemde burası liman diye geçmektedir. Bkz. İdris Bostan, "Tersane", DiA, C. XL, İstanbul 2011, s. 513. 
di. Şehir en yüksek tepesinde iç kale bulunmaktaydı. ${ }^{86}$ Boğazı kontrol eden noktada olması sebebiyle şehrin güvenliğini artırmak için etrafının ikinci bir surla çevrildiği anlaşılmaktadır. Ancak deprem esnasında bu surların çoğunun çökmesi yüzünden kent saldırıya açık hâle gelerek savunmasız kalmıştır.

Depremin gece meydana gelmesi ve hava koşullarının elverişsizliği yaşanabilecek kargaşanın şiddetini artırmış olmalıdır. Kantakuzenos, eserinde Gelibolu depremi ile ilgili verdiği bilgilerde hava durumunundan da bahsetmektedir. Onun kaydına göre, deprem şiddetli tipi ve sağanak yağışlarının olduğu bir gecede meydana gelmiştir. ${ }^{87} \mathrm{Bu}$ kargaşada depremin ardından sağ kalan halkın şehri aceleyele terk ettiği ve taşınabilir mallarını yanlarına alanların depremden etkilenmemiş yerlere kaçmaya çalıştıkları anlaşılıyor. Şiddetli depremin yıkıCı etkisi daha ziyâde Kuzey-Batı Marmara sahil yayında hissedildiğinden kenti terk edenler sahilin kuzeyine doğru ilerleyerek daha iç kesimlerdeki depremde hasar görmeyen kalelere yönelmiş olmalıdırlar. Ancak hava koşulları yüzünden pek çok kişinin, özellikle kadınlar ve çocukların dışarıda soğuktan hayatını kaybettikleri de anlaşılmaktadır. Sağ kalan halkın bir kısmı ise gemilerle oradan uzaklaşabilmiştir. Mora'ya gitmekte olan bir Bizans gemisinin kaptanı, felâketten sağ kurtulmayı başarıp o telâşla kendini denize atmış olan bazı kimseleri sudan çıkartarak Konstantinopolis'e götürmüştür. Depremin olduğu esnada Süleyman Paşa Pegai'de (Karabiga) bulunmaktadır. ${ }^{88}$

Süleyman Paşa surların yıkılması neticesinde savunmasız kalan şehri bir an önce ele geçirmek için kuvvetleriyle birlikte karşı yakaya geçmiştir. Depremin yarattığı bu kaos ortamı ve kendilerine direnecek herhangi bir kuvvetin kalmaması Osmanlıların kısa sürede kente hâkim olmalarını sağlamıştı. ${ }^{89}$ Süleyman Paşa gelişmelerin hemen ardından surları tamir ettirmiş ve Anadolu'dan getirttiği halkı bu bölgeye yerleştirmiştir. Depremin ardından savunmasız kalan şehirlerin çoğunu da kısa sürede ele geçirmiştir. Bundan sonra Süleyman Paşa, Trakya'da Bolayır-Gelibolu'dan hareketle sınırlarını Tekfurdağı ve Malkara yönünde geniş̧letmiştir. O, Gelibolu'yu Rumeli bölgesinde merkez edinip akınlarından sonra buraya dönmektedir. Nitekim onun Rumeli'deki fetihleri Migalkara (Malkara), İpsala, Seyitkavağı, Bolayır ve Gelibolu'dur. ${ }^{90}$

86 “Yıldııım Bayezid, Çanakkale Boğazı'nın korunması için Gelibolu merkez olmak üzere boğaz muhafızlı̆ııı kurmuş ve bașına da Saruca Paşa'yı görevlendirmiști. Saruca Paşa'nın ilk iş olarak Gelibolu'nun bir tepe üstünde bulunan iç kalesini takviye ettirmiş, dış kaleyi yıktırmış ve sunî limanı temizleterek liman ağzında iki kule inşa ettirmiştir. Bu liman gerektiğinde üç katlı bir zincirle kapatılabiliyordu." bu cümleden mütevellit Gelibolu şehrinin fizikî yapısı net bir şekilde ortaya çıkmaktadır. Bkz. İdris Bostan, "Saruca Paşa", DiA, C.XXXVI, İstanbul 2009, s. 168.

87 Nicol, a.g.e., s. 299.

88 Nicol, a.g.e., s. 299.

89 Gelibolu'nun fethi hususunda Osmanlı kaynaklarında kronolojik sorunlar bulunduğu ve Gelibolu'nun fethi meselesinin Çimpe Kalesi'nin ele geçirilişi ile ardından yaşanan hususlarla karıştı̆ı anlaşılmaktadır. Bu durum Prof. Dr. Halil İnalcık'ın yazdığı iki makalesinde ele alınmış ve dönemin diğer çağdaş kaynaklarıyla kroniklerde geçen hadiseler karşılaştırılarak bir kronoloji oluşturulmuştur. Bu hususta bkz. "Osmanlı Sultanı Orhan...", s. 8587; Halil İnalcık, "Batı Anadolu'da Yükselen...", s. 41-43. Ayrıca bu mevzu Prof. Dr. Feridun M. Emecen tarafından da tetkik edilerek konu ile sıkıntılı kısımlar üzerinde durulmuştur. Bkz. Feridun M. Emecen, ilk Osmanlılar ve Batı Anadolu Beylikler Dünyası, s. 65-67.

90 Halil İnalcık, "Rumeli", s. 233. 
1357'de Süleyman Paşa'nın bir kaza ya da suikastta hayatını kaybetmesi ve 1359'da Şehzâde Halil'in Foçalı korsanlar tarafından esir edilmesi Trakya fetihlerini akamete uğratmıştır.91 Şehzâde Halil'in kurtuluşundan sonra Şehzâde Murad Trakya'daki akınlara sistemli bir şeklide yeniden başlamıştır. Gelibolu'nun Osmanlıların eline geçmesi ise Konstantiopolis'te âdeta şok etkisi yaratmıştır. Trakya'ya güneyden gelebilecek tehditlerin önlenebileceği tek nokta olan Gelibolu'nun elden çıkmasının başkenti direkt hedef hâline getireceği korkusu üst safhaya ulaşmıştır. İfade etmek gerekmektedir ki, Gelibolu'nun Türkler tarafından alınmasının ardından Konstantinopolis'teki pek çok kişi Batı'ya gitmek için şehirden ayrılmıştır. ${ }^{92}$ Gelibolu'nun elden çıkması müşterek İmparator Kantakuzenos'un iktidarının sarsılmasına da yol açmıştır. ${ }^{93}$

Osmanlıların Bizans'tan aldığı ilk Trakya şehri olan Gelibolu depreminin yarattığı fiziksel hasarlar sebebiyle ne yazık ki bir hayli harap şekilde ele geçirilmişti. Şehrin konumu ve fonksiyonu gereği imar ve iskân meselelerinin öncelikli konu olduğu anlaşılmaktadır. Süleyman Paşa gelişmelerin hemen ardından surları tamir ettirmiş ve kentin stratejik önemine binâen yıkılan surların bazı kısımları da yeniden inşâ ettirilip eski hâline getirilmiştir. ${ }^{94}$ Genel olarak güvenlik sorununun yaşanmayacağı düşünülen yerlerde kale ve surlar kaderlerine terk edilirken özellikle sınır bölgelerindeki kaleler tamir ettirilerek fonksiyonel yapıları sürdürülmüştür. Gelibolu boğazın kontrol noktası olması sebebiyle kale ve surların mevcudiyetine büyük ehemmiyet verilmiştir. XV. yüzyılın ilk yarısında seyahati esnasında Gelibolu'dan geçen Pero Tefur notlarında Gelibolu'dan “...Bu (Gelibolu), Türklerin Yunanistan'a geçtikleri zaman işgal ettikleri ilk yerdi ve başka bir yerde yapmadıkları duvar ve kaleyi ayakta bıraktılar, böylece yenilgiye uğrarlarsa oradan yardım alabilirler." diye bahsederken kalenin ve surların güvenlik sebebiyle muhafaza altında olduğuna vurgu yapmıştır.95

Süleyman Paşa'nın âni vefatı sebebiyle şehrin imar işlerinin yarım kaldığı anlaşılmaktadır. Ancak Süleyman Paşa'dan sonra da Gelibolu diğer Osmanlı Sultanları tarafından ihtimamla korunup geliştirilmiştir. Daha sonra fethin bayrağını devralan Şehzâde Murad döneminde bu faaliyetlerin hız kazandığı söylenebilir. Sultan Murad tahta geçmesinin akabinde başkenti önce Dimetoka ardından da Edirne'ye taşımış ancak Gelibolu sahilinde de bir saray yaptırarak boğazdaki gemi geçişlerini zaman zaman buradan bizzat takip etmiştir. ${ }^{96}$

91 Süleyman Paşa'nın faaliyetleri ve vefatı hususunda ayrıntılı bilgi için bkz. Feridun M. Emecen, "Rumeli Fâtihi Süleyman Paşa'ya Dair Bazı Meseleler ve Notlar", Avrasya Incelemeleri Dergisi, 2017; VI/1, s. 6-7.

92 Alexander A. Vasiliev, a.g.e., s. 759.

93 Türkleri müttefik olarak çağırması ve sonucunda Gelibolu'nun Türklerin eline geçmesinden sorumlu tutulan Kantakuzenos, Konstantinopolis'te kendisine karşı oluşan muhalefet karşısında fazla dirâyet gösterememiş ve 10 Aralık 1354'te sarayda yapılan bir törenle, VI. loannes Kantakuzenos üzerindeki imparatorlara özgü bütün simgeleri çıkarıp keşiş cübbesi giymiştir. Bundan sonra manastıra kapanan Kantakuzenos “Imparator ve keşiş loannes Kantakouzenos" diye anılmaya başlamıştır. Eşi ve imparatoriçesi Eirene ise Eugenia adını alıp örtünerek manastır rahibesi olmuştur. Bkz. Nicol, a.g.e., s. 304.

94 Nicol, a.g.e., s. 299.

95 Pero Tafur, Travels and Adventures 1435-1439, London 1926, s. 114.

96 I. Murad'ın Gelibolu sahilinde bir saray yaptırdığı bilinmektedir, bkz. M. Tayyib Gökbilgin, XV-XVI. Asırlarda Edirne ve Paşa Livâsı (Vakıflar-Mülkler-Mukataalar), İstanbul 1952, s. 14. 
Surların aşağısında doğu yönündeki liman ise ilâvelerle eskisinden çok daha fonksiyonel bir hâle getirilmiştir. Nitekim Yıldırım Bayezid harap hâle gelmiş olan surları yeniden inşa ettirmiştir. 1390 yılında tersane inşâatına başlanmış ve işlevini yitirmiş olan dış kale yıkılmıştır. Buna mukabil bir tepe üzerinde olup hem şehre hem de limana hâkim olan iç kale ise güvelik sebebiyle tamir edilmiş kısmen bazı yerleri yeniden yapılmıştır. Çektiri sınıfı gemileri hem fırtına hem de kuvvetli düşman donanmalarının hücumlarından korumak üzere iç içe iki büyük havuzdan müteşekkil liman temizlenmiş ve güvenliği temin etmek amacıyla her iki limanın girişine ikişer sağlam kule inşa edilmiştir. Limanı gerekli durumlarda kapatmak üzere ise üç katlı zincir yapılmıştır. ${ }^{97}$

Çanakkale Boğazı'nı kontrol etmesi sebebiyle Gelibolu her zaman önemini korumuştur. 1354 depreminde şehrin neredeyse yok olduğu düşünüldüğünde Osmanlı fethi sonrası şehrin yeniden hayat bulduğu söylenebilir. Zîra kaynakların çoğunda belirtildiği üzere kent özellikle Katalan saldırıları esnasında oldukça harap bir hâle gelmiştir. Dolayısıyla 1300'lerin başından itibâren zaman zaman mâruz kaldığı saldırılar ve yaşanan depremler sebebiyle nüfusu gittikçe azalan şehir Osmanlıların sistemli iskân politikasıyla demografik anlamda da hareketlenmiştir. ${ }^{98}$.

Süleyman Paşa'nın vefatının ardından fetih hareketleri Şehzâde Murad'ın önderliğinde devam etmiştir. 0, Trakya'ya geçmek üzere kendi sancağı ve Karesi Sancağı'ndan müteşekkil olmak üzere çok sayıda askerle birlikte Lala Şahin'i de alarak Gelibolu'ya geçip oradan fetih hareketlerine devam etmiştir. Gelibolu'nun Osmanlıların eline geçmesiyle Bizans, Trakya savunma hattında en önemli üç şehrinden ilkini kaybetmişti. Başkent Konstantinopolis doğu ve güneyden Osmanlılar tarafından sıkıştııılmış, batı yönünde ise Trakya topraklarının en önemli iki kenti olan Dimetoka ve Edirne kalmıştır. Bu şehirlerin düşmesi ise başkentin Avrupa ile karadan olan bağlantısının kopması anlamına gelmekteydi. Şehzâde Murad'ın bundan sonraki politikasının bu kentleri ele geçirmek üzerine olduğu anlaşılmaktadır. Bu doğrultuda özellikle Trakya'nın merkezi kabul edilen Edirne üzerine odaklanılmıştır. ${ }^{99}$ Edirne özellikle XIV. yüzyıın başından itibâren tüm Trakya şehirleri gibi pek çok istilâ ve saldırıya mâruz kalmış ancak

97 Fevzi Kurtoğlu, a.g.e., s. 4. Dukas, Gelibolu'nun üç sıra kürekli kadırgaların barınabilmelerine müsait bir liman olduğundan, bunun müdâfaası için bir de muazzam kale inşa edildiğinden bahsetmektedir. Dukas, Bizans Tarihi, çev. VL. Mirmiroğlu, İstanbul 1956, s. 9.

98 Osmanlı kroniklerinde de belirtildiği üzere Gelibolu'nun fethinden sonra bölgeye Anadolu'dan yoğun bir nüfus akışı söz konusudur. XV. yüzyılın ikinci yarısında şehirde neredeyse sadece Müslümanlar bulunmaktadır. Gelibolu'ya ait mevcut en eski tarihli (h. 879/1475) tahrir defterine göre şehrin merkezinde 40 Müslüman mahallesi bulunmaktayken gayrimüslim mahallesine ise rastlanmamaktadır. bkz. IAK, MC. nr. 0. 79, v.1a- 13a. Şehrin dışında olduğu tespit edilen gayrimüslim nüfus mezkûr defterde "hâneha-yı haymana" olarak kaydedilmiştir. Cemaat olarak kaydedilmiş olan bu grupların bir kısmı nefs-i Gelibolu'da bir kısı da Kitre, Maydos ve Kozludere köylerinde yerleşmiştir. Gelibolu'ya tâbi olanların sayısının altı cemaât olduğu görülmektedir. Bkz. MC. nr. 0.79,v. 45a-46a.

99 Edirne, Bizans'ın İstanbul ve Selânik'ten sonra en önemli şehri olarak nitelendirilmektedir, bkz. Halil İnalcık, “Edirne'nin Fethi”, Edirne'nin 600. Fethi Yıldönümü Armağan Kitabı, Ankara, 1993, s. 137-159. Ayrıca bu hususta bkz. Halil İnalcık, “Sultan Orhan”, s. 97. 
güçlü surlara sahip olmasının avantajıyla yüzyılardır ayakta da kalmayı başarabilmiştir. Öyle ki en son Katalanların Trakya içlerindeki hücumlarından Dimetoka ve Edirne yalnızca güçlü surları sayesinde kurtulmuşlardı. ${ }^{100}$

Dikdörtgen biçiminde bir kale olan Edirne surları İmparator Hadrianus tarafından inşa edilmiş, l. lustinianos tarafından kuvvetlendirilmişti. Kalenin köşelerinde dört muazzam burç ve bu burçlar arasında dört köşeli 12'şer daha ufak kuleler ile dokuz kapısı bulunmaktaydı. ${ }^{101}$ Bu vasıflardaki bir şehri ele geçirmek ise anlaşılacağı üzere bir hayli zor olacaktır. Keza Dimetoka da çift kat surlarıla meşhur bir kentti. Şehirlerin bu denli güçlü savunma sistemine sahip olmaları Osmanlıların fetih yönteminde de belirleyici rol oynamıştır. Bu doğrultuda Şehzâde Murad öncelikli olarak Edirne'nin etrafıyla irtibatını keserek şehri yalnızlaştırmak suretiyle direncinin kırılması yönünde bir politika izlemiştir.

Dönem hakkında bilgi veren kronikler incelendiğinde bu hedef doğrultusunda Osmanlı kuvevtlerinin iki koldan hareket ettiği anlaşılmaktadır. Şehzâde Murad ve Lala Şahin'in önderliğinde birinci grubun Gelibolu'dan başlamak üzere kuzey Marmara sahil yayını takip edilerek İstanbul yönüne ve yine hemen bu güzergâhın kuzeyini içine alacak şekilde harekete geçtiği görülmektedir. Hacı İlbey ve Gazi Evrenos'un önderliğindeki ikinci grubun ise Edirne'nin güneyini kontrol altına almak üzere Dimetoka tarafına gönderildiği anlaşılmaktadır. ${ }^{102}$ Fetih politikası doğrultusunda her iki cihette harekâtın eş zamanlı olarak başladığı ancak Dimetoka'nın Edirne'den daha önce ele geçirildiği anlaşıımaktadır.

Trakya savunma hattının önemli bir halkasını oluşturan Dimetoka'ya ilk akınların daha Süleyman Paşa zamanında yapıldığı görülmektedir. Dimetoka stratejik olarak Trakya'nın önemli kentlerinden biri olmasının yanı sıra yukarıda da değinildiği üzere Bizans iç savaşları döneminde müşterek imparatorlarının zaman zaman yönetim merkezi olması hasebiyle de siyasî bir önem taşımaktaydı. Burası önce niyâbet makamı ardından da müşterek imparatorun ikametgâhı olmuştur. Kantakuzenos, Trakya soylularının desteğini alarak burada kendini imparator ilân etmiş̧tir. ${ }^{103}$ Benzer bir şekilde, Edirne de ortak impatarorların yönetim merkezi olmuştur. Bu sebeple Dimetoka ve Edirne'nin vaktiyle İznik'in misyonuna benzer bir özelliğe sahip oldukları söylenebilir. İznik'in hem Türkiye Selçuklu Devleti'ne hem de Bizans'a başkentlik yapmış olması, Osmanlılar için Selçukluların Anadolu'daki vârisi misyonunu üstlenmelerini sağlamanın yanı sıra Bizans'ın tahtına ortak olunabileceği fikrini de beraberinde ge-

100 Nicol, a.g.e., s. 167.

101 Semavi Eyice, "Bizans Devrinde Edirne ve Eserleri” Edirne'nin 600. Fethi Yıldönümü Armağan Kitabı, Ankara, 1993, s. 65.

102 Âşıkpaşazâde, s. 125-127.

103 Nicol, a.g.e., s. 194- 235. 
tirmiştir. ${ }^{104}$ Dimetoka ve Edirne'nin I. Murad zamanında bir biri ardına Osmanlı'ya başkentlik yapmış olmaları bu fikri doğrular mâhiyettedir. Ayrıca bu düşüncenin fetih sürecinde mânevî bir motivasyon oluşturduğu da muhakkaktır. Dimetoka'nın fethi tüm bunların yanı sıra Edirne'nin fethini de kolaylaştıracaktır.

Edirne'yi güney yönde Meriç Vadisi üzerinden koruyan Dimetoka, uç beyleri tarafından baskı altında tutulmaya başlanmıştır. Ancak kentin oldukça güçlü bir savunma sistemine sahip oluşu başlı başına bir sorun teşkil etmektedir. Dimetoka ismi de bu özelliğine istinâden şehre verilmiştir. Ülkenin batı yönünde savunma hattının bir parçası olan kent, İmparator Trajanus (98-117) tarafından düzlük arazide kurulan Plotinopolis'in yerine inşa edilmişti. Barbar istilâları sırasında tahrip olunca İmparator I. Iustinianos tarafından Kızıl Deliçay Nehri'yle çevrili platoda tekrar kurulmuştur. Yeniden tesis edilirken şehir çift surla çevrildiği için buraya "çift surlu" anlamına gelen Grekçe Didymóteichon adı verilmiş ve bu isim Osmanlı döneminde Dimetoka şeklini almıştır. ${ }^{105}$ Tarihî süreç dikkate alındığında Dimetoka'nın neredeyse Bizans İmparatorluğu'nun kuruluşundan itibâren Trakya savunmasında önemli bir rol üstlendiği anlaşılmaktadır.

Kuruluş yeri amacına uygun olarak ovaya hâkim olan bir yüksek tepe üzerinde olup batı ile güney yönünde Kızıldeli Nehri ile çevrelenmiştir. Surların güvenliğini arttırmak amacıyla önünde bir hendeğe gerek duyulmaması, kuzey ile doğu yönünde uzanan surların sarp kayalıklardan geçmesi ve ayrıca batı ile güney yönünde yüksek debisiyle doğal bir hat oluşturan Kızıldeli Nehri'nin bulunuyor olması sebebiyledir. Ancak güvenliği üst seviyede tutmak için surların içinde Gelibolu'daki yapıya benzer şekilde bir iç kale bulunduğu görülmektedir. ${ }^{106}$

Bu güçlü surlara sahip şehrin kısa sürede alınması imkân dâhilinde görünmüyordu. Osmanlı kaynaklarından edinilen bilgiler Dimetoka'nın Konurhisar'da bulunan Osmanlı kuvvetleri tarafından sürekli olarak tazyik edildiği yönündendir. ${ }^{107}$ Konurhisar, zaptının ardından Osmanlı uç beylerinden Hacı İlbey'in yönetimine verilmişti. ${ }^{108}$ Dimetoka'nın fethi için görevlendirilen Hacı İlbeyi, buradan hareketle Evrenos Bey ve diğer gazilerle birlikte Dimetoka'yı kuşatma altına almak için yoğun çaba sarf etmiştir. Bu doğrultuda Dimetoka sistemli bir şekilde Osmanlı akınlarına mâruz kalmıştır. Ancak bu akınların Süleyman Paşa'nın vefatıyla birlikte Trakya fetihlerinin akamete uğradığı süreçte durmuş olduğu anlaşılmaktadır.

104 Kutalmışoğlu Süleyman Şah İznik ve civarını fethedip İznik başşehir olmak üzere Anadolu'nun ilk Türk devletini, Türkiye Selçuklularını kurmuştur (1078), bkz. Sevim-Yücel, a.g.e., s. 100-103. Bizans kaynakları Süleyman Şah'ın 1078 yılında İznik'te oturduğunu doğrulamaktadır, bkz.: Osman Turan, Selçuklular Zamanında Anadolu Alp Arslan'dan Osman Gazi'ye (1071-1318), İstanbul 1971, s. 54. İznik'in Süleyman Şah tarafından ele geçirilerek merkez yapılması hususu daha sonra Bizans'ın eline geçen kentin Anadolu'daki Türkmenler tarafından yeniden fethinin kutsal bir misyon olarak kabul edilmesine yol açmıştır. İznik 19 Haziran 1097 tarihinde Bizans'a teslim olmuştur. Bkz. Sevim-Yücel, a.g e., s. 113.

105 Machiel Kiel, “Dimetoka”, DiA, C. IX, İstanbul 1994, s. 305.

106 Evliya Çelebi Dimetoka Kalesi'ni detaylı bir şekilde tasvir etmektedir. Bkz. Evliya Çelebi, Seyahatnâme, haz. Seyit Ali Kahraman, 8/2, İstanbul 2001, s. 69-70.

107 Anonim Osmanlı Kroniği (1299-1512), haz. Necdet Öztürk, İstanbul 2000, s. 22; Neşrî, s. 195.

108 Abdülkadir Özcan, “Hacı İlbey”, DiA, C. XIV, İstanbul 1996, s. 482. 
Şehzâde Murad'ın idâresinde yeniden fetih hareketlerinin başladığı dönemde Dimetoka tekrar muhasara edilmeye başlanmıştır. Osmanlı kuvvetleri bu kez şehre daha yakın bir bölgeyi üs edinince şehrin üzerindeki baskı da hissedilir derecede artmıştır. Osmanlı kaynakları Hacı Ilbeyi'nin Meriç kenarında bir burgozu (küçük hisar) ele geçirdiği ve buradan Dimetoka'yı sıkı bir denetim altına aldığından bahsetmektedir. ${ }^{109}$ Meriç Nehri üzerinde ileri bir noktada bulunan bu burgoz Pythion'dur (Burgos veya Illbey Burgosu). ${ }^{110}$ Burası Osmanlı idâresinde Kuleliburgos adını almış olup bugün Dimetoka'nın yaklaşık 16 kilometre kuzey doğusundaki Pythion Köyü'dür. ${ }^{111} \mathrm{Hacı}$ lilbey'in emrindeki kuvvetler Dimetoka'ya oldukça yakın bu hisarda gündüzleri dinlenip geceleri ise Dimetoka Kalesi'ne âni baskınlar yapmaktaydılar. Dimetoka tekfurunun Osmanlıların bu gece saldırılarına karşı hazır beklediği ve savunmada bulunduğu anlaşılmaktadır. Osmanlı kroniklerinde Dimetoka fethinin bahsi geçtiği kısımlarda yine bu gece saldırıları esnasında mezkûr tekfurun ele geçirilmesi neticesinde kalenin fethedildiği bildirilmektedir. ${ }^{112}$ Bununla birlikte kaleyi Osmanlılara teslim etmesi şartıyla kendisinin ve ailesinin şehri terk etmesine müsâade edilmiştir. Bu suretle Dimetoka Kalesi Hacı llbey tarafından fethedildiğinde halkın can ve mal güvenliğinin teminat altına alınmış olduğu görülmektedir. ${ }^{113}$

Şehir halkının Osmanlı idârecileri tarafından korunup kollanması onların yerlerinde kalmalarını sağlamış ve herhangi bir çatışma olmaksızın teslim olmaları kentte muhtemel can kayıplarının da önüne geçmiştir. XIV. yüzyıl Bizans Dimetokası'nın nüfusu hakkında herhangi bir kayıt olmamasına rağmen bazı çıkarımlara göre şehrin o zamanki nüfusunun 1.600-2.000 kişi civarında olduğu tahmin edilmektedir. ${ }^{114}$ Ancak Bizans'ın son zamanlarında yani Osmanlı fethi esnasında surların dışında da yerleşimin olduğu anlaşılmaktadır. ${ }^{115}$ Fakat Osmanlı baskınları sebebiyle burada yaşayanların kale içine ya da henüz Osmanlıların eline geçmemiş olan Edirne Kalesi'ne sığınmış olmaları da muhtemeldir. Osmanlıların bölgede ilerlediği esnada bazı kentlerin ahâlisi yerlerini terk ederek daha güvenli bir bölge olduğunu düşündükleri Edirne'ye kaçmışlardır.

Dimetoka Osmanlı idâresine geçtikten sonra öncelikli olarak I. Murad zamanında idârî ve fizikî bakımdan gelişme kaydetmiştir. Osmanlı fethi sonrasında şehrin savunmasını güçlendirmek adına sur içinde birbiriyle irtibatı iki iç kalenin daha yapıldığı anlaşılmaktadır. Kalenin içindeki hünkâr sarayı bu zamanda yaptıııımış olmalıdır. ${ }^{16}$ Zîra Edirne başkent oluncaya kadar Sultan Murad burayı yönetim merkezi olarak kullanmıştır.

109 Anonim Osmanlı Kroniği (1299-1512), s. 27; Âşıkpaşazâde, s. 122-127; Neşrî, s. 193-195.

110 Abdülkadir Özcan, a.g.m., s. 482.

111 Bugün Dimetoka Belediyesine bağlı Evros kasabasının bir köyüdür.

112 Âşıkpaşazâde, s. 127; Neşrî, s. 195.

113 Anonim Tevârîh-i Âl-i Osman, (F. Geise neşri), haz. N. Azamat, İstanbul 992, s. 24.

114 Machiel Kiel, XIV. yüzyılda şehrin sur içinde kalan kısmının 20 hektar olduğu ve Bizans kentlerinde hektar başına genellikle 80-100 kişi düştüğü varsayımıyla yaklaşık nüfusu tahmin etmiştir. Bkz. "Dimetoka”, s. 305.

115 Nicol, a.g.e., s. 240; Machiel Kiel, a.g.m., s. 305.

116 Evliya Çelebi Dimetoka Kalesi'ndeki iç kale kısmında bir bölme hisar yapıldığııı, bunun padişah için ayrı bir bölme olduğunu söyleyerek Hünkâr Sarayı'nın bu bölmede olduğundan bahsetmektedir. Dimetoka Kalesi'nin özellikleri için bkz. Evliya Çelebi, Seyhatnâme, 8/2 s. 69-70. 
Dimetoka'nın ele geçirilmesiyle Bizans'ın Trakya savunma hattında bir şehir daha Osmanlılara teslim olmuş, geriye bu hat üzerinde sadece Edirne kalmıştır. Edirne önceki kısımlarda da zikredildiği üzere tıpkı Dimetoka gibi siyasî ve stratejik özellikleri hâiz bir kentti. Dimetokanın hemen ardından Keşan Hisarı da Gazi Evrenos tarafından ele geçirilmiş ve bu defa da İpsala baskı altına alınmıştı. ${ }^{117}$ Böylece Gelibolu-Dimetoka arasındaki güzergâh kesintisiz bir şekilde Osmanlıların denetimine geçmiştir. Bu hadiseler gerçekleştiği esnada Şehzâde Murad da emrindeki diğer kuvvetlerle birlikte yukarıda birinci güzergâh olarak isimlendirilen, Gelibolu-İstanbul arasında bulunan ve olası Edirne kuşatması esnasında şehre gelebilecek yardımların önünü kesmek üzere bu kent ile başkent Konstantiopolis arasındaki işlek yol üzerindeki kaleleri ele geçirmekle meşguldü. Bununla birlikte Şehzâde Murad ilk olarak Gelibolu üzerinden hareketle kuzeydoğu yönünde ilerleyerek Marmara sahilindeki Bantoz (Banados) Hisarı'na yürüyüp burayı herhangi bir muharebe olmaksızın ele geçirdi. Bu sebepten kale halkına dokunulmadı. Oradan kuzey yönünde Çorlu taraflarına geçilerek hisar üzerine hareket edildi. Osmanlı kuvvetleri bu defa burada ciddi bir savunmayla karşılaştılar. Ancak Çorlu tekfuru kaleyi savunurken gözünden yaralanınca kalenin mukavemeti kırıldı ve müdâfaasız kalan kale Osmanlı gazilerince ele geçirilip yüklü miktarda ganimet elde edildi. Daha sonra burasının Osmanlılara karşı bir karargâh olma ihtimâline karşı kale yakılarak tahrip edildi. ${ }^{118}$

Çorlu'dan hareketle Misini'ye gelindi ki burda önce bir direnişle karşılaşılmasına rağmen kalenin sulh üzere teslim edildiği anlaşılmaktadır. Edirne'ye giden yol üstündeki yerler bir bir ele geçirilmekteydi. Misini'den hareket eden Osmanlı kuvvetleri Burgus'a (Lüleburgaz) geldiler fakat burada hisarı terk edilmiş bir şekilde buldular. ${ }^{119}$ Bu boş hisar da Osmanlı kuvvetlerince ateşe verilerek kullanılmaz hâle getirildi. ${ }^{120}$ Buradaki kalelerde bulunan halkın Osmanlı saldırılarından kurtulmak ve canlarını kurtamak için Trakya'da henüz Osmanlıların eline geçmemiş tek şehir olan Edirne'ye sığınmak üzere kalelerini terk ettikleri görülmektedir. ${ }^{121}$ Bu sebepten olsa gerek Osmanlı kuvvetleri Burgos (Lüleburgaz) Kalesi'nden sonra Eski'ye (Babaeski) geldiklerinde hisarı terk edilmiş hâlde bulmuşlardır. ${ }^{122}$ Osmanlı kroniklerden anlaşıldığına göre ahâlisiyle ele geçirilen kalelerdeki halkın can ve mallarına dokunulmamak üzere anlaşma yapılmış ve kaleler tahliye edilmek suretiyle teslim alınmışlardır. ${ }^{123}$

117 Âşıkpaşazâde, s. 127.

118 Âşskpaşazâde, s. 126. Broquiere İstanbul'dan Edirne'ye seyahati esnasında Çorlu'dan geçtiği sıradaki notlarında zengin otlakları olan geniş bir vadide kurulan şehrin Sultan I. Murad tarafından kuşatıldığııı ve sonrasında savaşarak burayı aldığından bahsetmektedir. Muharebe esnasında Osmanlı kuvvetleri tarafından kenti koruyan vâlinin kafasının kesildiğini, askerlerinin katledildiğini ve kalenin yerle bir ediliğini de ifade etmektedir. Bertrandon De la Broquierenin Denizaşırı Seyahati, yay. haz. Ch. Schefer, çev. İlhan Arda, İstanbul 2000, s. 229.

119 Burası bugün Tekirdağ Ili, Ergene Ilıçesi'ne bağlı Misinli Köyü olup kalenin bir burç ve duvar kalıntısını günümüze ulaşmıştır.

120 Âşıkpaşazâde, s. 126.

121 Neşrî, s. 195.

122 Neşrî, s. 195-196.

123 Âşıkpaşazâde, s. 127. 
Şehzâde Murad'ın Eski'yi bir karagâh olarak kullandığı anlaşılmaktadır. Kendisi burada kalmak üzere lalası Şahin'in yanına bir kısım kuvvetler vererek onu Edirne'ye göndermiştir. Bu arada Hacı İlbeyi ve Gazi Evrenos kendi kuvvetleriyle Dimetoka'da gelişmeleri yakından takip etmekte ve Edirne harekâtına çağırılma hususunda haber beklemekteydiler. ${ }^{124}$ Osmanlı kuvvetleri Edirne'ye yaklaşııklarında Edirne Tekfuru onları çok sayıda askerle karşılamıştır. Edirne'nin stratejik öneme sahip olması sebebiyle askerin burada fazlaca bulunması beklenmeyen bir durum değildi. Ancak Edirne'ye gelen güzergâh üzerinde özellikle Bergos ve Eski kalelerinin boş olması buradaki asker ve halkın Edirne'yi müdâfaa etmek üzere şehre geldikleri düşüncesini kuvvetlendirmektedir. Bu suretle Osmanlılara karşı kentin korunmasında takviye kuvvetlerin bulunması savunmayı güçlendirecektir. Ancak Edirne yakınlarında iki kuvvet arasında yaşanan şiddetli çarpışmanın neticesi Bizanslıların beklentisinden oldukça uzaktır. Sazlu-dere'de gerçekleşen muharebede Osmanlı kuvvetleri büyük bir başarı kazanmıştır. ${ }^{125}$ Bunun üzerine Edirne'ye karşı son harekâtın yapılması için Şehzâde Murad'ın Dimetoka'da bekleyen kuvvetlere haber gönderdiği anlaşılmaktadır. ${ }^{126}$ Onun kuvvetlerine Hacı İlbey ile Gazi Evrenos'un kuvvetleri katılarak Edirne önlerindeki Lala Şahin'in kuvvetleriyle birleşmişlerdir. Bundan sonra Osmanlı kuvvetleri Edirne'ye gelmiş fakat hiç bir mukavemetle karşılaşmamışlardır. Şehre geldikleri günün gecesinde Edirne Tekfuru, Meriç Nehri'nin yükselmesini fırsat bilip bir kayıkla Enez'e oradan da İstanbul'a kaçmıştır. Gece tekfurun kaçtığını öğrenen Edirne halkı ise herhangi bir mukavemet göstermeksizin şehrin kapısını Osmanlılara açmışlardır. ${ }^{127}$

Bu teslim oluşun ardında Edirne-İstanbul bağlantısının tamamen kopmuş olması ve kente gelebilecek yardımların ortadan kalkmasının büyük etkisi olduğu söylenebilir. Yukarıda da değinildiği üzere savunması güçlü şehirleri ele geçirmenin en iyi yöntemi kentin diğer bölgelerle bağlantısını kesmekle mümün olmuştur. Bu hususta geleneksel abluka altına alma yönteminin oldukça iyi neticeler verdiği anlaşılmaktadır. Ancak şunu da belirtmek gerekir ki 1352 yılında Kantakuzenos'un oğlu Mattheos'a Süleyman Paşa denetiminde yardıma gelen Osmanlı kuvvetlerinin kentte yapmış olduğu tahribatlar, halkın hafızasında canlıı̆ını korumuş olacak ki aynı neticeyle karşılaşmak istememeleri de teslim olmalarında etkili olmuş olabilir. Edirne Kalesi teslim olduğunda içindeki halk yerinde kalmış ancak surların dışında kalanlar ise kenti terk etmişlerdir. Şehrin teslimi esnasında ikame ettikleri kentten ayrilan kimi halk daha sonra yerlerine döndüklerinde evlerini ve dükkânlarını yerli yerinde bulmuşlardır. ${ }^{128}$ Edirne'nin kendi rızasıyla teslim olması sebebiyle halkına hiç bir zarar verilmediği ve kentte barış ortamının hâkim olduğu söylenebilir.

124 Dimetoka daha Şehzâde Murad'ın Çorlu taraflarında olduğu sıralarda ele geçirilmiş, ardından İpsala ise baskı altına alınmıştı. Âşıkpaşazâde, s. 126-127.

125 Halil İnalcık, "Edirne'nin Fethi”, s. 149.

126 Âşıkpaşazâde, s. 127; Neşrî, s. 197.

127 Halil İnalcık, “Osmanlı Sultanı Orhan”, s. 97. Ayrıca bu hususta bkz. Halil İnalcık, “Edirne’nin Fethi”, s. 149; Keza bkz. Âşıkpaşazâde, s. 127.

128 Süheyl Ünver, “Edirne Medeniyetimiz ve Tezyini”, Edirne'nin 60. Fethi Yıldönümü Armağan Kitabı, Ankara 1993, s. 236. 
Edirne, Bizans idâresinde kale içinden müteşekkil küçük bir kentti. ${ }^{129}$ Osmanlılar kenti fethettiklerinde ilk olarak kale içinde yerleşmişler ancak çok geçmeden surların dışında da yeni yerleşim alanları iskâna açıımıştır. Osmanlı idaresinin ilk yıllarından itibâren şehir Anadolu'dan yeni gelenlerle birlikte hem fiziksel hem de demografik olarak büyüme göstermiştir. Şehzâde Murad, Osmanlı tahtına geçtikten sonra batıya yapılacak seferlerin önemine binâen Bursa'daki sarayı buraya taşımıştır (1365). ${ }^{130}$

\subsection{Trakya Kırsal Alanında Yaşanan Gelişmeler}

XIV. yüzyıl Trakyası'nda kentlerin yanı sıra kırsal alan da büyük tahribata uğramıştır. Kırsal alanda yaşayanların güçlü surlar içinde hayatta kalmaya çalışan şehirlilerden çok daha zor zamanlar geçirdikleri muhakkaktır. Surların dışında kalanların hem can hem de mal güvenliği tehlike altında idi. Köylüler canlarını kurtarmak adına kimi zaman tarlalarını, bağlarını ve çiftliklerini terk edip en yakındaki kalelere sığınırken kimi zaman da ekili arazilerinin ya da bağlarının yakılmasına şahit olmaktaydılar. Her ne şekilde olduğu fark etmeksizin netice itibarıyla arazilerini kullanamaz durumda kalıyorlardı. Yüzyıllardır tarımsal zenginliği ile bilinen münbit Trakya toprakları XIV. yüzyılın özellikle ilk yarısında artık ekilemez hatta kimi zaman ekilse dahi mahsuller toplanamaz hâle gelmişti. Bu durum sadece mezkûr köylülerin değil aynı zamanda besin ihtiyacını bölgeden karşılayan başkent Konstantinopolis'i de yakından ilgilendirmekteydi. Zîra başkent Konstantinopolis'i besleyen en önemli tedarik coğrafyası Doğu'da Bitinya, Batı'da ise Trakya topraklarıydı. ${ }^{131}$ Ancak imparatorluk 1330'ların sonunda “Konstantinopolis'in bahçesi” olarak adlandırılan zengin Bitinya topraklarını Osmanlılara terk etmek zorunda kalmıştı. ${ }^{132}$ Geriye ellerinde sadece Trakya toprakları kalmıştı.

XIV. yüzyılın ilk yarısında Katalanlar ve hemen onun ardından denizci Türkmenler tarafından talan edilmiş olan Trakya arazileri kaynakların da sık sık zikrettiği üzere çöle dönmüştü. Yukarıda da değinildiği üzere Katalanların başkent Konstantinopolis'e gelme ihtimâli üzerine II. Andronikos yol üzerinde yiyecek tedariki yapabilecekleri her kaynağı ortadan kaldırmak amacıyla Selymbria (Silivri) ile Konstantinopolis arasındaki bütün arazilerin boşaltılması ve hatta ürünlerin yakılması için bizzat emir vermişti. Ardından gelen iç muharebelerin etkileri

129 Edirne'ye ait mevcut en eski tahrir defterine göre XVI. yüzyılın başlarında şehirde 19 zımmî (Hıristiyan) mahalle mevcuttur. Bkz. BOA, TT.d., nr.77, s. 42- 48; Bu sayı XVI. yüzyılın sonlarına doğru da aynı kalmıştı, bkz. Feridun M. Emecen, "Tarih Koridorlarına Bir Sınır Şehri: Edirne”, Edirne: Serhattaki Payitaht, haz. E. Nedret İşli-M. Sabri Koz, İstanbul 1998, s. 62. Bu veriler doğrultusunda Osmanlı fethi esnasında Edirne Kaleiçi'nde kaç mahalle olduğu hakkında az da olsa bir fikir sahibi olmak mümkündür. Nitekim XVI. yüzyılda Edirne'den geçen Busbecq kentin eski surlarla çevrili bölümün pek büyük sayılmadığını, ancak surların dışında Türklerin ilâve ettiği binalarla büyük ve geniş bir kent hâline geldiğinden bahsetmektedir. Bkz. Ogier Ghislain De Busbecq, Türk Mektupları, çev. Derin Türkömer, İstanbul 2005, s. 26.

130 i. Hakkı Uzunçarşılı, a.g.e., s. 170.

131 Jacques Lefort, “13. Yüzyılda Bithiynia”, Osmanlı Beyliği (1300-1389), ed. Elizabeth Zachariadou, Türkçe trc. Gül Çağalı Güven, vd., İstanbul 1997, s. 106-107.

132 1300'lerin başında Osman Bey ile başlayan fetih hareketleri neticesinde en son 1337'de İzmit'in ve hemen sonrasında da Üsküdar'a kadar ilerleyen Osmanlılar yaklaşık 35-40 yıl içinde tüm Bitinya bölgesinin fethi gerçekleşmiştir. 
yine kentlerde olduğu kadar kırsal alan da şiddetli şekilde hissedilmiştir. Tarım arazileri kullanılmaz hâle gelirken buralarda yaşayan köylüler ve çiftçiler de yerlerinden olmuşlardı. İç savaşlar döneminde ise taraflar arasında yaşanan mücadeleler, çatışmalar yine köy ve kırsal alanda yaşayanların aleyhine bir durum oluşturmuştu.

Kantakuzenos'un müttefiki olarak Trakya'ya geçen Osmanlı kuvvetleri önce Gelibolu-Dimetoka ardından da Gelibolu-Edirne güzergâhında yaptıkları harekat esnasında önlerine gelen çiftlikleri yakıp yıkmıştı. Osmanlılar Dimetoka taraflarında iken Bizans idâresinden herhangi bir yardım gelmeyeceğini anlayan çiftçiler eşit olmayan koşullardaki mücadeleyi bırakıp en yakın kentlerin surları arkasına çekilmişlerdi. ${ }^{133}$ Edirne'de ise surların dışındaki bağlar Kantaokuzenos'u desteklemeyen Edirne halkını cezalandırmak amacıyla onun emriyle yakılıp talan edilmişti. ${ }^{134}$

Savaşlar ve çatışmaların yaratığı kaos ortamı Trakya arazilerini tarım yapılamaz hâle getirmiş, kırsal alandaki halk daha güvenli yerlere gitmek üzere arazilerini ve çiftliklerini terk etmek zorunda kalmışlardı. Yerlerini terk eden köylülerin ya en yakın şehirdeki kaleye ya da daha çok iç kesimlerden kaçarak sahildeki köy ya da kasabalara geldikleri anlaşılmaktadır. Trakya bölgesi kırsal alanı incelendiğinde nüfusun eskiye oranla çok az olduğunu söylenebilir. Zîra Bizans kaynakları da nüfusun muharebeler, depremler ve salgın hastalıklar sebebiyle azalmış olduğuna vurgu yapmaktadır. Bu durum Osmanlı fethi sonrasında Trakya kırsalında neden yüzlerce Türkçe isim taşıyan köyün bulunduğu konusuna da açıklık getirmektedir. Kentler ve kırsal alanla ilgili tutulmuş Osmanlı kayıtlarında yüzlerce Türkçe adlı köy bulunmasına karşın, kadim köy ismine çok az rastlanması dikkat çekicidir. Grekçe (Rumca) köy isimlerinin sayısının çok az olması ya da bu dildeki adlara bazı yerlerde hiç rastlanmaması elbetteki buralarda Bizans köyleri olmadığı ve tarım yapılmadığı anlamını taşımamaktadır. Zîra başkent Konstantinopolis'in iâşesinin temini için organize edilmiş Trakya köylerinde tarım yapılmıyor olması akla yakın değildir. Ancak yukarıda bahsedildiği üzere yaşanan koas ortamı köylerin boşalmasına ve nüfussuz kalmasına sebep olmuştur.

Osmanlı vesikalarında bu konuya ışık tutacak kayıtlar mevcuttur. Örneğin; Trakya'da ilk fethedilen bölge olan Gelibolu ve çevresiyle ilgili Gelibolu tahrir defterleri ilk yerleşimler hakkında ayrıntılı bilgi vermektedir. Gelibolu Sancağı'na bağlı Malkara Kazası'nda bulunan Hırala Köyü'ndeki Hıristiyan nüfus için “kadîmî kullar" ifadesi dikkat çekicidir. Ayrıca Kozludere'de ise bir vakıf kaydında "kadîm de kâfiri kovan" Hacı Hızır'ın vakfı bilgisi de önceden burada yerli halkın yaşadığı hakkında mâlûmat vermektedir. ${ }^{135}$ Yine Tekirdağ ve Edirne kırsal alanında rastlanılan benzer ifadeler de buralarda eskiden yerleşim yerleri olduğunu göstermektedirler. "Kadimden kâfir ekermiş"136 ya da artık mevcut olmamasına rağmen sadece belgelerde adı kalan "kilise

133 Nicol, a.g.e., s. 325.

134 Nicol, a.g.e., s. 298.

135 Halil İnalcık, "Sultan Orhan", s. 102.

136 BOA, T.d., nr. nr. 50, s. 216. 
deresi", 137 "kâfir yermiş", 138 “kâfir pınarı"139 gibi tanımlayıcı ibârelerin yanı sıra Müslümanlar tarafından koyulmadığı açık olan “domuz pınarı", 140 “domuz viranı", 141 “donuzcu deresi”'142 gibi tâbirler de yine buralarda daha önceden gayrimüslim nüfusun yaşadığının göstergesidir.

Gelibolu-Tekirdağ-Malkara-Çorlu-Vize arasındaki kırsal alanlar incelendiğinde gayrimüslim köy sayısının yine çok az olduğu hatta bazı yerlerde hiç bulunmadığı dikkat çekmektedir. Örneğin Tekirdağ-Malkara-Çorlu arasında hatta Çorlu'nun büyük bir kısmı da dâhil olmak üzere gayrimüslim köy ismine rastlanmamaktadır. ${ }^{143}$ Halbuki bu bölgeler Edirne-Gelibolu-İstanbul güzergâhında en işlek yollar üzerinde nüfusun yoğun olduğu verimli arazilerdi. Fakat öyle görünüyor ki bu bölgeler Osmanlı ilerleyişi esnasında terk edilmişlerdi.

Fetih bölümünde bahsedildiği üzere özellikle Edirne'nin fethi esnasında Şehzâde Murad öncelikli olarak Edirne-İstanbul bağlantısını kesmek üzere Banados-Çorlu-Burgos-Eski hattındaki kentleri ele geçirmişti. Bu esnada Banados halkının mukavemet göstermeden teslim olması üzerine halkına dokunulmadığı kayıtlıdı. Ancak Çorlu halkı Osmanlı kuvvetleri karşısında teslim olmayıp savaştıkları için muharebe sonrasında kale yağmalanmış ve kullanılmaz hâle getirilmişti. Yine Burgos ve Eski'ye varıldığında ahâlinin şehirleri terk ettiği görülmüştü. Fetih esnasında bölge halkının Osmanlı kuvvetlerine karşı tutumu halkın akıbetinde belirleyici rol oynamıştır sonucu çıkarılabilir. Dolayısıyla özellikle Edirne-İstanbul güzergâhındaki arazilerin boş ve Osmanlı iskânına açık olması burada Türk köylerinin sayısının fazla olmasında etkili olmuştur. Nitekim Banados kendiliğinden teslim olduğu için fetih sonrasında da yerli ahâli tarafından aynı bölgede meskûn olduğu görülmektedir. ${ }^{144}$ Dolayısıyla dönemin kroniklerindeki bilgiler ile Osmanlı tahrir kayıtlarındaki bilgiler birbirini teyît eder niteliktedir. Netice itibarıyla Osmanlı arşiv vesikalarında rastlanılan geçmiş dönemlere atfedilen bilgiler, Osmanlı ilerleyişi esnasında Rum halkın köylerini terk etmeleri neticesinde arazilerin büyük kısmının boş olduğu ve Osmanlı fethini müteakip Anadolu'dan gelen Türkmenler tarafından buralarda iskân faâliyetlerinin yürütüldüğünü göstermektedir.

137 RŞS (=Rodoscuk Şeriyye Sicili), nr. 1518, 42a.

138 M. Münir Aktepe, “XIV. ve XV. Asırlarda Rumeli'nin Türkler Tarafından İskânına Dair", Türkiyat Mecmuası, C. X, İstanbul 1953, s. 302.

139 M. Tayyib Gökbilgin, a.g.e., s. 56.

140 RŞS, nr. 1583, 32a.

141 M. Tayyib Gökbilgin, a.g.e., s. 56.

142 M. Tayyib Gökbilgin, a.g.e., s. 216.

143 BOA, MAD, nr. 35, 39/b- 111/a.

144 Banados, XVI. yüzyılın başlarında alıı Rum mahallesinden müteşekkil olup kasabada sayıları yaklaşık 1.550 kişiyi bulan Rum yaşamaktaydı. Bunun yanı sıra kasabadaki 14 Müslüman hâne ise muhtelif Rum mahallelerinde dağınık yaşamakta olup müstakil bir Müslüman mahallesi bulunmamaktaydı. Bkz. Hacer Ateş, Kuzey Marmara Sahilleri ve Art Alanında Şehirleşmenin Tarihi Süreci: XVI-XVII. Yüzyıllarda Tekirdağ ve Yöresi, İstanbul Ünivesitesi Sosyal Bilimler Ensitüsü Yayınlanmamaş Doktora Tezi, İstanbul 2009, s. 38-39. Keza yine bu hususta bkz. BA, $T D$, nr. 50, s. 237- 242. 


\section{Sonuç}

XIV. yüzyılın ilk yarısında Anadolu'daki topraklarını Türklere terk etmek zorunda kalan Bizans idâresi, Avrupa'daki topraklarını korumakta da başarısız olmuştur. Yüzyılın ikinci yarısına doğru başlayan isyanlar ve iç savaşlar imparatorluğu idârî ve siyasî açıdan zora sokmuştur. Bu süreçte en çok Konstantinolopis'in güvenliğinin teminatı olarak görülen Trakya bölgesinin etkilendiği görülmektedir. Rakip güçlerin birbirlerine karşı verdiği mücadelelerde müttefik arayışları Trakya'nın elden çıkmasına sebep olacak gelişmeleri beraberinde getirmiştir. Müşterek İmparator VI. Ioannes Kantakuzenos'un müttefiki sıfatıyla Trakya topraklarına geçen Osmanlı kuvvetleri bu vesileyle yeni bir coğrafî bölgeyi tanıma imkânı bulmuşlar ve nihayetinde de ittifaktan bağımsız hareket etmeye başlamışlardır.

Bizans idâresinin Osmanlı ilerleyişini önleyecek kudrette olamaması fetih hareketlerinin hız kazanmasını ve uygulanan fetih yöntemleri de Trakya'daki önemli şehirlerin Osmanlı hâkimiyetine geçmesini sağlamıştır. Ancak Osmanlı fethi öncesinde şehirlerin ve kırsal alanın mâruz kaldığı çeşitli istilâlar, doğal afetler ve salgın hastalıkların şehirlerin mukavetinin kırılmasında etkili olduğunu da belirtmek gerekir. Bu kaos ortamının kentlerin fizikî ve demografik yapısında derin izler bıraktığı anlaşılmaktadır. Bizans kaynakları bu süreçte Trakya şehirlerinde ve kırsal alanında ciddi nüfus azalması olduğunu doğrulamaktadır. Halkı dağılmış ve terk edilmiş olan arazilerin büyük kısmı iskâna açık hâle gelmiştir. Osmanlılar bölgeyi fethettikten sonra bu boş alanları şenlendirilmek için Anadolu'dan büyük Türkmen gruplarını Trakya taraflarına nakletmişler ve sistemli bir iskân politikasıyla yeni yerleşim alanları oluşturulmuştur. Netice itibarıyla kısmî duraklamalara rağmen Trakya'nın önemli kentleri yaklaşık 10 yıl içerisinde Osmanlılar tarafından fethedilmiştir. Osmanlıların Trakya'da yerleşmeleri bundan sonra Balkanlara yapılacak seferlerin de önünü açmıştır. Trakya'nın elden çıkması ile Bizans İmparatorluğu'nun Avrupa ile karadan teması kesilmiş ve her yönden çevrilmiş olan Konstantinopolis doğrudan hedef hâline gelmiştir.

\footnotetext{
Hakem Değerlendirmesi: Dış bağımsız.

Çıkar Çatışması: Yazar çıkar çatışması bildirmemiştir.

Finansal Destek: Yazar bu çalışma için finansal destek almadığını beyan etmiştir.

Peer-review: Externally peer-reviewed.

Conflict of Interest: The author has no conflict of interest to declare.

Grant Support: The author declared that this study has received no financial support.
} 


\section{Bibliyografya}

\section{1-Arşiv Belgeleri}

a- Devlet Arşivleri Başkanlığı Osmanlı Arşivi (BOA)

TT.d. (Tapu Tahrir Defterleri), nr. 50; nr.77.

MAD. (Mâliyaden Müdevver Defterler), nr. 35.

\section{b- Şeriyye Sicilleri}

RŞS (Rodoscuk Şeriyye Sicili), nr.1518; nr.1583.

\section{c- İstanbul Belediyesi Atatürk Kitaplığı}

MC (Muallim Cevdet Yazmaları), nr. 0. 79.

\section{2- Kaynak Eserler}

Anonim Osmanlı Kroniği (1299-1512), haz. Necdet Öztürk, İstanbul 2000.

Anonim Tevârîh-i Âl-i Osman, (F. Geise neşri), haz. N. Azamat, İstanbul 992.

Âşıkpaşazâde, Tevârih-i Âl-i Osman, haz. N. Atsız, Osmanlı Tarihleri-l, İstanbul 1949.

Dukas, Bizans Tarihi, çev. VL. Mirmiroğlu, İstanbul 1956.

Neşrî, Kitâb-ı Cıhan-Nümâ (Neşrî Tarihi), yay. haz. Faik Reşit Unat- Dr. Mehmed A. Köymen, I. Cilt, Ankara 1949.

Enverî, Düsturnâmei Enverî (Medhal), haz. Mikrimin Halil, Türk Tarih Encümeni Külliyatı S:15, İstanbul 1929. Pachymeres, Georges, Bizanslı Gözüyle Türkler, çev. İlcan Bihter Barlas, İstanbul 2009.

Procopius, Bizans'ın Gizli Tarihi, çev. Orhan Duru, İstanbul 2001.

\section{3- Seyahatnâmeler}

Bertrandon De la Broquierenin Denizaşırı Seyahati, yay. haz. Ch. Schefer, çev. İlhan Arda, İstanbul 2000. Busbecq, Ogier G. , Türk Mektupları, çev. Derin Türkömer, İstanbul 2005.

Evliya Çelebi, Seyahatnâme, haz. Seyit Ali Kahraman, C.8/2, İstanbul 2001.

Tafur, Pero, Travels and Adventures 1435-1439, London 1926.

\section{4- Kitap ve Makaleler}

Akın, Himmet, Aydınoğulları Tarihi Hakkında Bir Araştırma, Ankara Üniversitesi Yayınları, No. 60, Ankara 1968.

Aktepe, M. Münir “XIV. ve XV. Asırlarda Rumeli'nin Türkler Tarafından İskânına Dair”, Türkiyat Mecmuası, C. X, İstanbul 1953, s. 299-312.

Aktepe, M. Münir, Osmanlıların Rumeli'de Illk Feth Ettikleri Çimbi Kal'ası", Tarih Dergisi, C.I, S.2, İstanbul 1950, s. 283-308. 
Ateş, Hacer, Kuzey Marmara Sahilleri ve Art Alanında Şehirleşmenin Tarihi Süreci: XVI-XVII. Yüzyıllarda Tekirdağ ve Yöresi, İstanbul Ünivesitesi Sosyal Bilimler Ensitüsü Yayımlanmamış Doktora Tezi, İstanbul 2009.

Ateş, Hacer, “Kuzey Marmara'da Bir Liman Kentinde Ticaret: XVI. Yüzyılda Tekirdağ-Rodoscuk Limanı”, Trakya Üniversitesi Edebiyat Fakültesi Dergisi, Cilt: 3, sayl: 6, Temmuz-2013, s. 21-38.

Ayönü, Yusuf, Osmanlılardan Önce Rumeli'de Türkler (1305-1313), Tarih İncelemeleri Dergisi, Cilt/XXI, sayı: 2, Aralık 2006, s. 17-33.

Ayönü, Yusuf, Katalanların Anadolu ve Trakya'daki Faaliyetleri (1302-1311), Ege Üniversitesi Yayınları No:158, İzmir 2009.

Başkan, Yahya “Orhan Bey'in Bizans İmparatoru Kantakuzeneos'un Kızı Theodora ile Evliliği”, Tarih Dergisi, sayl: 66 (2017/2), İstanbul 2017, s. 47-61.

Baştav, Şerif , “Osmanlı İmparatorluğu'nun Kuruluşu Esnasında Bizans ve Avrupa”, Belleten, LXVIII, sayl: 251, s. 63-104.

Baştav, Şerif, Bizans Imparatorluğu Tarihi Son Devir (1261-1461) Osmanlı Türk-Bizans Münasebetleri, Ankara 1989.

Baykara, Tuncer, Anadolu'nun Tarihi Coğrafyasına Giriş I - Anadolu'nun Idari Taksimatı, Ankara 1988.

Bostan, İdris, "SarucaPaşa”, DIA, C. XXXVI, İstanbul 2009, s. 168-169.

Bostan, İdris, "Tersane”, DIA, C. XL, İstanbul 2011, s. 513-516.

Dağtekin, Hüseyin, “Türkleri Boğazlar Bölgesi'ne Çeken Gerçek Sebepler”, AÜDTCF Dergisi, XIX/3-4, Ankara1962, s. 177-187.

Emecen, Feridun M., “Gelibolu”, DIA, C. XIV, İstanbul 1996, s. 1-6.

Emecen, Feridun M., “Tarih Koridorlarına Bir Sınır Şehri: Edirne”, Edirne: Serhattaki Payitaht, haz. E. Nedret İşli- M. Sabri Koz, İstanbul 1998, s. 49-69.

Emecen, Feridun M., Ilk Osmanlılar ve Batı Anadolu Beylikler Dünyası, İstanbul 2010.

Emecen, Feridun M., “Aydınoğlu Umur Bey: Kısa Bir Biyografi Denemesi”, Uluslararası Batı Anadolu Beylikleri Tarih, Kültür ve Medeniyet Sempozyumu-I- Aydınoğulları Tarihi (Bildiriler), TTK Yayınları, S. 4., Ankara 2013.

Emecen, Feridun, "Saruhan Oğulları Beyliği”, Anadolu Beylikleri El Kitabı, ed. Haşim Şahin, Ankara 2016, s.144-145.

Emecen, Feridun M., “Rumeli Fâtihi Süleyman Paşa'ya Dair Bazı Meseleler ve Notlar”, Avrasya Incelemeleri Dergisi, 2017; VI/1, s. 1-8.

Eyice, Semavi, “Kale”, DIA, C. XXIV, İstanbul 2001, s. 234-242.

Eyice, Semavi, “Bizans Devrinde Edirne ve Eserleri” Edirne'nin 600. Fethi Yıldönümü Armağan Kitabı, Ankara, 1993.

Gökbilgin, M. Tayyib, XV-XVI. Asırlarda Edirne ve Paşa Livâsı (Vakıflar-Mülkler-Mukataalar), İstanbul 1952. İlgürel, Mücteba, “ístimâlet”, DiA, C. XXIII, İstanbul 2001, s. 362-363.

İnalcık, Halil, “Edirne'nin Fethi”, Edirne'nin 600. Fethi Yıldönümü Armağan Kitabı, Ankara, 1993.

İnalcık, Halil, "Batı Anadolu'da Yükselen Denizci Gâzi Beylikleri, Bizans ve Haçlılar”, Türk Denizcilik Tarihi, C. I, ed. İdris Bostan-Salih Özbaran, İstanbul 2009, s. 31-48.

İnalcık, Halil, “Osmanlı Sultanı Orhan (1324-1362) Avrupa'da Yerleşme”, Belleten, LXXIII, S: 266, Ankara 2009, s. 77-107.

İnalcık, Halil, “Rumeli”, DIA, C.XXXV, İstanbul 2008, s. 232- 235. 
İnalcık, Halil, “Bursa”, DIA, C.VI, İstanbul 1992, s. 445-449.

İnbaşı, Mehmet, “Üsküp”, DIA, C. XLII, İstanbul 2012, s. 377-381.

Kaplan, Michael “imparatorluğun Midesi”, Konstantinopolis 1054-1261, ed. Alain Ducellier-Michel Balard, çev. Can Belge, (iletişim Yay). İstanbul 2002, s. 83-99.

Kılıç, Şahin, Bizans Kısa Kronikleri, İstanbul 2013.

Kiel, Machiel, “Dimetoka”, DiA, C. IX, İstanbul 1994, s. 305-308.

Koçuk, İsmail, İznik Bizans Devleti Tarihi Kuruluş Devri (1204-1214), İstanbul Üniversitesi Sosyal Bilimler Enstitüsü Yayımlanmamış Yüksek Lisans Tezi, İstanbul 2017.

Kordatos, Yannis, Bizans'in Son Günleri, çev. Muzaffer Baca, İstanbul 2006.

Kurtoğlu, Fevzi, Gelibolu ve Yöresi Tarihi, İstanbul 1938.

Lefort, Jacques, “13. Yüzyılda Bithiynia”, Osmanlı Beyliği (1300-1389), ed. Elizabeth Zachariadou, Türkçe trc. Gül Çağalı Güven, vd., İstanbul 1997.

Nicol, Donald M., Bizans'ın Son Yüzyılları 1261-145, çev. Bilge Umar, İstanbul 2016.

Ostrogosky, Georg, Bizans Devleti Tarihi, çev. Fikret Işıltan, Ankara 2011.

Ozansoy, Esin, "Bizans Kaynaklarına Göre 1200-1453 Depremleri”, Tarih Boyunca Anadolu'da Doğal Âfetler ve Deprem Semineri, 22-23 Mayıs 2000, İstanbul 2001, s. 1-27.

Öden, Zerrin Günal, “Bizans İmparatorluğu'nun Türkler'e Karşı Alan ve Katalanlar ile İttifakı”, IÜEF Tarih Dergisi, S. 35, İstanbul 1994, s. 123-130.

Öden, Zerrin Günal, Karası Beyliği, TTK Yayınları, S. 166, Ankara 1999.

Özcan, Abdülkadir, “Hacı İlbey”, DiA, C. XIV, İstanbul 1996, s. 482.

Pirenne, Henri, Ortaçağ Avrupasının Ekonomik ve Sosyal Tarihi , çev.Uygur Kocabaşoğlu, İstanbul 2009.

Sevim, Ali-Yaşar Yücel, Türkiye Tarihi- Fetih, Selçuklu ve Beylikler Dönemi, Ankara 1989.

Süheyl Ünver, “Edirne Medeniyetimiz ve Tezyini”, Edirne’nin 60. Fethi Yıldönümü Armağan Kitabı, Ankara 1993.

Turan, Osman, Selçuklular Zamanında Anadolu Alp Arslan'dan Osman Gazi'ye (1071-1318), İstanbul 1971. Uzunçarşılı, I. Hakkı Osmanlı Tarihi, C.I, Ankara 1988.

Vasiliev, Alexander A., Bizans Imparatorluğu Tarih, çev. Tevabil Alkaç, İstanbul 2016.

Zachariadou, Elizabeth A., “Karesi ve Osmanlı Beylikleri: İki Rakip Devlet”, Osmanlı Beyliği (1300-1389), ed. Zachariadou, Elizabeth A., çev. Gül Çağlı Güven vd..., İstanbul 1997, s. 243-255. 